\title{
Hedgehog: functions and mechanisms
}

\author{
Markku Varjosalo and Jussi Taipale ${ }^{1}$ \\ Department of Molecular Medicine, National Public Health Institute (KTL), and Genome-Scale Biology Program, \\ Biomedicum Helsinki, Institute of Biomedicine and High Throughput Center, Faculty of Medicine, University of Helsinki, \\ Helsinki FI-00014, Finland
}

\begin{abstract}
The Hedgehog (Hh) family of proteins control cell growth, survival, and fate, and pattern almost every aspect of the vertebrate body plan. The use of a single morphogen for such a wide variety of functions is possible because cellular responses to $\mathrm{Hh}$ depend on the type of responding cell, the dose of $\mathrm{Hh}$ received, and the time cells are exposed to $\mathrm{Hh}$. The $\mathrm{Hh}$ gradient is shaped by several proteins that are specifically required for $\mathrm{Hh}$ processing, secretion, and transport through tissues. The mechanism of cellular response, in turn, incorporates multiple feedback loops that fine-tune the level of signal sensed by the responding cells. Germline mutations that subtly affect $\mathrm{Hh}$ pathway activity are associated with developmental disorders, whereas somatic mutations activating the pathway have been linked to multiple forms of human cancer. This review focuses broadly on our current understanding of $\mathrm{Hh}$ signaling, from mechanisms of action to cellular and developmental functions. In addition, we review the role of $\mathrm{Hh}$ in the pathogenesis of human disease and the possibilities for therapeutic intervention.
\end{abstract}

The origin of the name Hedgehog derives from the short and "spiked" phenotype of the cuticle of the Hh mutant Drosophila larvae. Mutations in the $H$ h gene were identified by Nusslein-Volhard and Wieschaus (1980) in their large-scale screen for mutations that impair or change the development of the fruit fly larval body plan. Drosophila Hh DNA was cloned in the early 1990s (Lee et al. 1992; Mohler and Vani 1992; Tabata et al. 1992; Tashiro et al. 1993). In addition to Drosophila, Hh genes have also been found in a range of other invertebrates including Hirudo medicinalis (leech) and Diadema antillarum (sea urchin) (Chang et al. 1994; Shimeld 1999; Inoue et al. 2002). It is important to note that the model organism Caenorhabditis elegans (roundworm) has no Hh ortho$\log$, even though it has several proteins homologous to the Hh receptor Ptc (Kuwabara et al. 2000).

Hh orthologs from vertebrates-including Mus musculus (mouse), Danio rerio (zebrafish), and Gallus gallus

[Keywords: hedgehog; signal transduction; cancer; development; transcription]

${ }^{1}$ Corresponding author.

E-MAIL jussi.taipale@helsinki.fi; FAX 358-9-1912-5554.

Article is online at http://www.genesdev.org/cgi/doi/10.1101/gad.1693608.

Freely available online through the Genes \& Development Open Access option. (chicken)-were cloned in 1993 (Echelard et al. 1993; Krauss et al. 1993; Riddle et al. 1993; Chang et al. 1994). Cloning of the first Rattus rattus (rat) and human $\mathrm{Hh}$ genes were reported shortly thereafter, in 1994 and 1995, respectively (Roelink et al. 1994; Marigo et al. 1995). The vertebrate genome duplication (Wada and Makabe 2006) has resulted in expansion of the $H$ h genes, which can be categorized into three subgroups: the Desert Hedgehog (Dhh), Indian Hedgehog (Ihh), and Sonic Hedgehog (Shh) groups (Echelard et al. 1993). The Shh and Ihh subgroups are more closely related to each other than to the Dhh subgroup, which in turn is closest to Drosophila Hh. Avians and mammals have one $H$ h gene in each of the three subgroups, but due to another whole-genome duplication (Jaillon et al. 2004) and further rearrangements, zebrafish has three extra Hh homologs, one in the Shh subgroup: tiggywinkle hedgehog (Twhh) (Ekker et al. 1995), and two others in the Ihh group; echidna hedgehog (Ehh) (Currie and Ingham 1996); and qiqihar hedgehog (Qhh) (Fig. 1A; Ingham and McMahon 2001).

Components of the $\mathrm{Hh}$ signal transduction pathway have been identified primarily using Drosophila genetics (for example, see Lee et al. 1992; Alcedo et al. 1996; van den Heuvel and Ingham 1996; Burke et al. 1999; Chamoun et al. 2001; Jacob and Lum 2007b). Mechanisms by which the Hh signal is transduced has been further characterized using Drosophila and mouse cell culture models (Fig. 1B,C; e.g., see Kinto et al. 1997; C.H. Chen et al. 1999; Chuang and McMahon 1999; Taipale et al. 2000; Lum et al. 2003a; Nybakken et al. 2005; Varjosalo et al. 2006). In both vertebrates and invertebrates, binding of $\mathrm{Hh}$ to its receptor Patched (Ptc) activates a signaling cascade that ultimately drives the activation of a zinc-finger transcription factor (Ci in Drosophila, GLI1-3 in mammals), leading to the expression of specific target genes (Huangfu and Anderson 2006; Jacob and Lum 2007a; Varjosalo and Taipale 2007).

Although many of the key components are conserved in vertebrates, the mammalian Hh signaling pathway is incompletely understood and harbors some differences and additional pathway components (see below). It was long thought that the main difference between Drosophila and mammalian Hh signaling was that mammals had multiple orthologs of many pathway components, including $\mathrm{Hh}, \mathrm{Ptc}$, and $\mathrm{Ci}$. However, the roles of mammalian orthologs of two critical components of the 
A

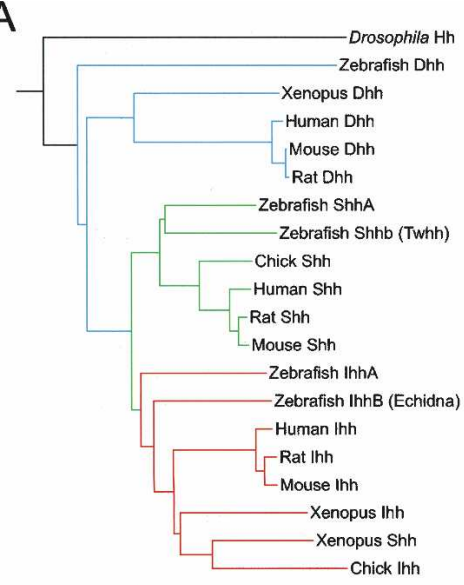

B
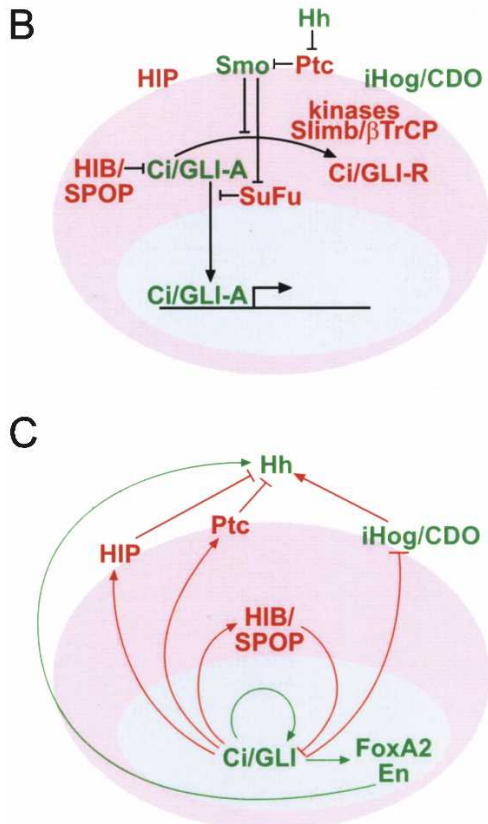

Figure 1. (A) Phylogram illustrating the evolution of the $\mathrm{Hh}$ proteins. The different Hh proteins were aligned using Prankster (Loytynoja and Goldman 2005). Hh subgroups are indicated by a color code, as follows: Dhh (blue), Shh (green), and Ihh (red). $(B)$ The central conserved components of the Hh signaling pathway and their role in forward signaling. Positively and negatively acting pathway components are in green and red, respectively. Note that most interactions between components are inhibitory. The conserved kinases involved in regulation of $\mathrm{Ci} /$ GLI processing from activator forms (Ci/GLI-A) to repressor forms (Ci/GLI-R) are casein kinases (CKs) $1 \alpha$ and $1 \varepsilon$, glycogen synthase kinase-3 $\beta$ (GSK3 $\beta$ ), and protein kinase A (PKA). (C) The four negative (red) and two positive (green) transcriptional feedback loops of the Hh pathway. Ci/GLI-positive feedback to itself is mediated by GLI1 in mammals. HIP and FoxA2 are only found in vertebrates, and Engrailed (En) has been characterized as a regulator of Hh only in Drosophila. Both Drosophila and mammalian names of the components are given separated by a slash.

Drosophila pathway, the protein kinase Fused $(\mathrm{Fu})$ and the atypical kinesin Costal2 (Cos2), appear not to be conserved (Chen et al. 2005; Merchant et al. 2005; Svard et al. 2006; Varjosalo et al. 2006). This suggests that the mechanisms of Hh signal transduction from the receptor to the Ci/GLI transcription factors have evolved differentially after separation of the vertebrate and invertebrate lineages approximately 1 billion years ago (Hedges 2002; Varjosalo and Taipale 2007).

\section{Developmental functions and expression of mammalian Hh proteins}

The Hh proteins act as morphogens controlling multiple different developmental processes (Fig. 2). All mammalian Hh proteins are thought to have similar physiological effects-the differences in their roles in development result from diverse pattern of expression (McMahon et al. 2003; Sagai et al. 2005).

Dhh expression is largely restricted to gonads, including sertoli cells of testis and granulosa cells of ovaries (Bitgood et al. 1996; Yao et al. 2002; Wijgerde et al. 2005). Consistent with its expression in a very narrow tissue range, Dhh-deficient mice do not show notable phenotypes is most tissues and are viable. However, males are infertile due to complete absence of mature sperm (Bitgood et al. 1996).

Ihh is specifically expressed in a limited number of tissues, including primitive endoderm (Dyer et al. 2001), gut (van den Brink 2007), and prehypertrophic chondrocytes in the growth plates of bones (Vortkamp et al. 1996; St-Jacques et al. 1999). Approximately 50\% of $I h h^{-/-}$embryos die during early embryogenesis due to poor development of yolk-sac vasculature. Surviving embryos display cortical bone defects as well as aberrant chondrocyte development in the long bones (St-Jacques et al. 1999; Colnot et al. 2005). Homozygous hypomorphic mutations of $I H H$ in humans cause acrocapitofemoral dysplasia, a congenital condition characterized by bone defects and short stature (Hellemans et al. 2003).

$\mathrm{Shh}$ is the most broadly expressed mammalian Hh signaling molecule. During early vertebrate embryogenesis, Shh expressed in midline tissues such as the node, notochord, and floor plate controls patterning of the leftright and dorso-ventral axes of the embryo (Sampath et al. 1997; Pagan-Westphal and Tabin 1998; Schilling et al. 1999; Watanabe and Nakamura 2000; Meyer and Roelink 2003). Shh expressed in the zone of polarizing activity (ZPA) of the limb bud is also critically involved in patterning of the distal elements of the limbs (Riddle et al. 1993; Chang et al. 1994; Johnson et al. 1994; Marti et al. 1995). Later in development, during organogenesis, Shh is expressed in and affects development of most epithelial tissues (Fig. 2).

Deletion of Shh leads to cyclopia, and defects in ventral neural tube, somite, and foregut patterning. Later defects include, but are not limited to, severe distal limb malformation, absence of vertebrae and most of the ribs, and failure of lung branching (Chiang et al. 1996; Litingtung et al. 1998; Pepicelli et al. 1998).

The different Hh ligands often act in the same tissues during development, and can function partially redundantly (Fig. 2). For example, Shh and Ihh act together in 


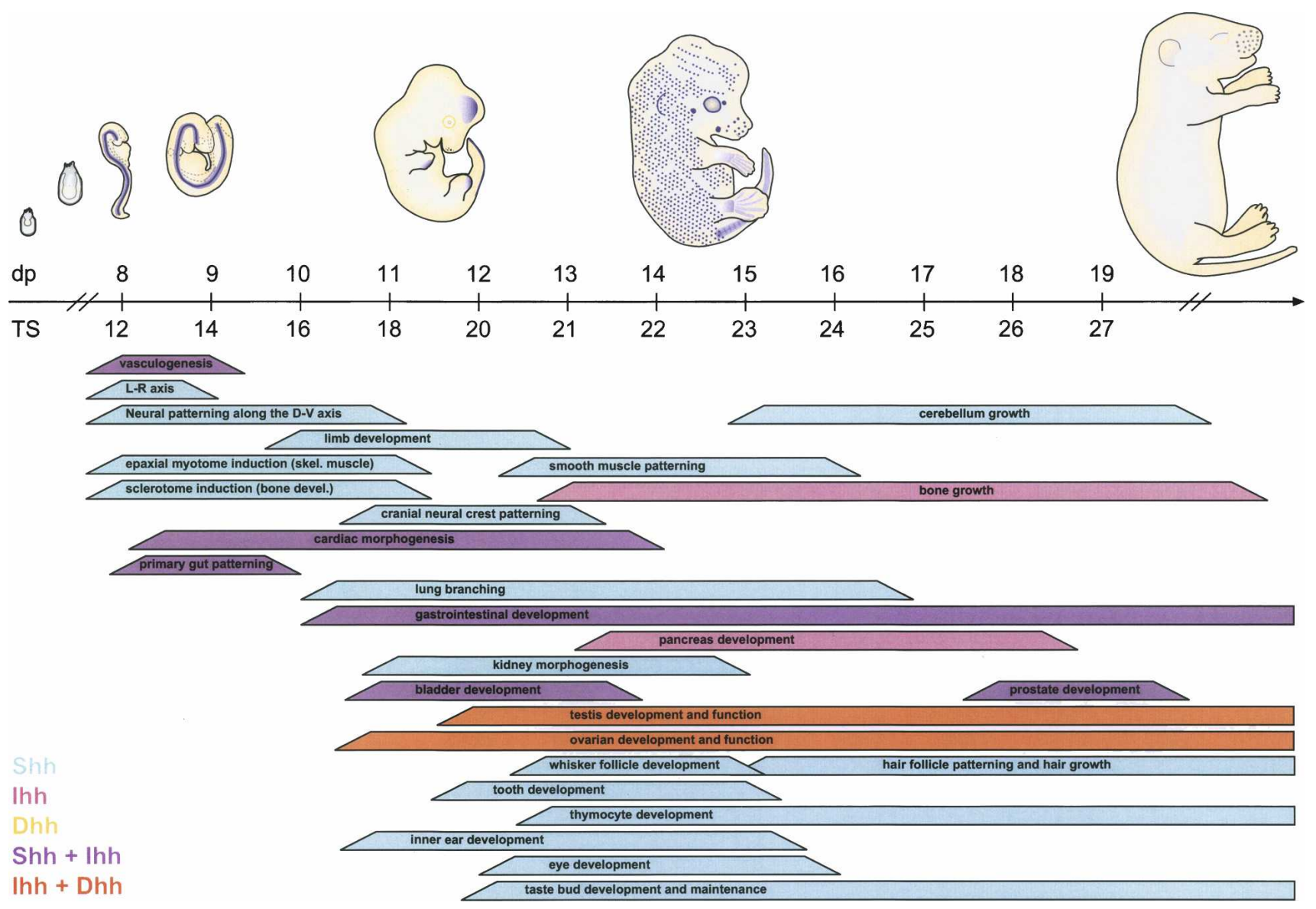

Figure 2. Shh controls mouse development from an embryo to an adult. (Top) The embryo cartoons show aspects of expression of the Hh target gene patched (blue) during mouse embryonic development. (Bottom) Bars show approximate embryonic stages when Shh, Ihh, and/or Dhh (color code in bottom left) control developmental processes in the indicated tissues or cell types. The approximate embryonic stage is indicated by dpc and Theiler stage (TS) (Theiler 1989). References: the role of Hh in early embryogenesis prior to TS 15 (Chiang et al. 1996; Zhang et al. 2001; Astorga and Carlsson 2007); limb development (Ahn and Joyner 2004); cranial neural crest (Jeong et al. 2004); cardiac septation (Goddeeris et al. 2008); gastrointestinal system (Madison et al. 2005); bladder (Haraguchi et al. 2007); lung (White et al. 2007); prostate (Berman et al. 2004); pancreas (Hebrok et al. 2000); testis development (Yao et al. 2002); retina (Sigulinsky et al. 2008); kidney (Hu et al. 2006); hair (St-Jacques et al. 1998; Jeong et al. 2004); taste buds (Miura et al. 2001); ear (Riccomagno et al. 2002); ovary (Wijgerde et al. 2005; Pangas 2007); tooth (Cobourne et al. 2001, 2004); bone growth (St-Jacques et al. 1999); cerebellum growth (Hatton et al. 2006; Sillitoe and Joyner 2007).

early embryonic development, and their combined loss phenocopies the loss of the $\mathrm{Hh}$ receptor component Smoothened (Smo), leading to early embryonic lethality due to defects in heart morphogenesis and extraembryonic vasculogenesis (Zhang et al. 2001; Astorga and Carlsson 2007).

\section{Regulatory elements affecting mammalian $\mathrm{Hh}$ expression}

Of the mammalian Hh genes, only the mechanisms controlling Shh expression have been studied in detail. The expression pattern of $S h h$ is the result of the combined action of multiple enhancer-elements, which act independently to control Shh transcription in different tissues and expression domains. Both local-acting and very distal elements have been identified (Fig. 3).
Two independent enhancers-Shh floor plate enhancer 1 (SFPE1) and SFPE2, located at $-8 \mathrm{~kb}$ and in intron 2, respectively-act to direct reporter expression exclusively to the floor plate of the hindbrain and spinal cord (Epstein et al. 1999). A third element in intron 2, Shh brain enhancer 1 (SBE1), directs reporter expression to the ventral midbrain and caudal diencephalon. The more distal elements SBE2, SBE3, and SBE4, which are located $>400 \mathrm{~kb}$ upstream of the Shh transcription start site (TSS) drive reporter expression in the ventral forebrain. The combined activity of these enhancers appears to cover all regions of Shh transcription along the anterior-posterior axis of the mouse neural tube (Jeong et al. 2006).

The enhancer controlling Shh expression in the ZPA of limb buds, mammals-fish conserved sequence 1 (MFCS1), is located even further upstream of the start 


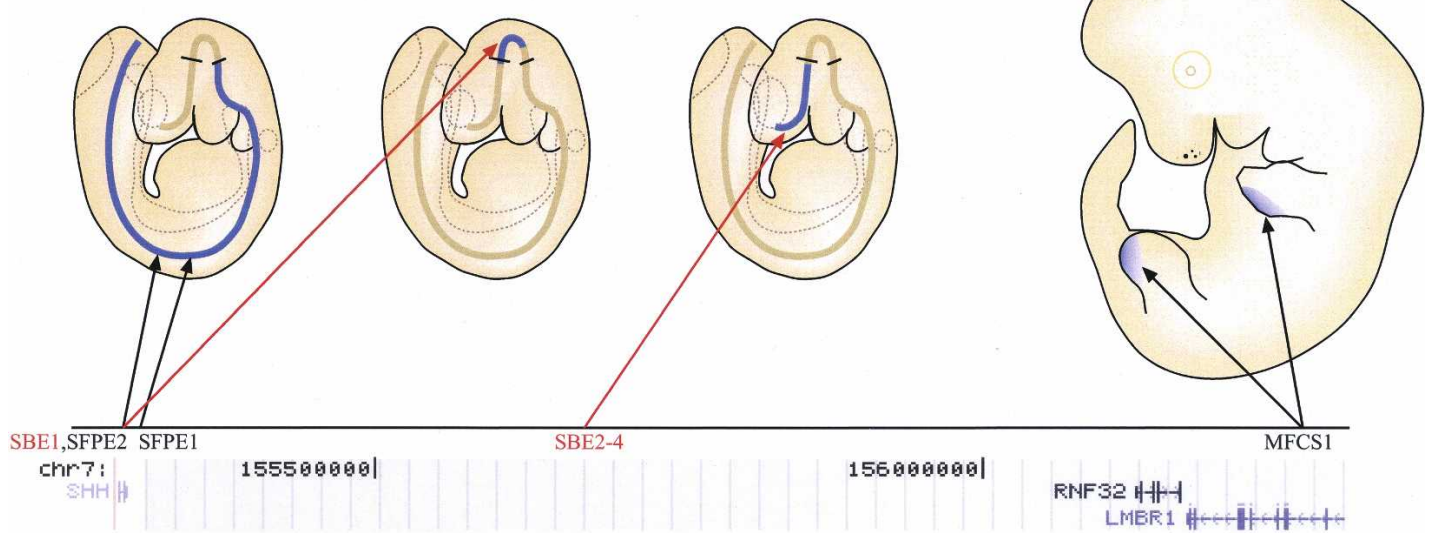

Figure 3. Regulation of mammalian Sh gene expression. (Top) Enhancer-elements driving expression of the mouse Shh gene in different neural domains (left) and in posterior margin of the embryonic limb buds (right). Approximate expression domains of the elements are indicated by blue color. Black lines perpendicular to the neural tube indicate zona limitans intrathalamica (ZLI) and midbrain-hindbrain junction. (Bottom) Known genes in the $\sim 1 \mathrm{Mb}$ genomic region upstream of the human Shh gene (University of California at Santa Cruz genome browser, assembly 36). Note that only one transcriptional start site of another gene appears to be between the most distal conserved Shh enhancer (MFCS1) and the Shh gene itself.

site, at $-1 \mathrm{Mb}$ in intron 5 of the Lmbr1 gene (Sharpe et al. 1999; Lettice et al. 2003; Sagai et al. 2004). This element is the only enhancer in Shh that has been analyzed also by loss-of-function studies (Sagai et al. 2005), which conclusively demonstrate that MFCS1 is necessary for Shh expression in mouse ZPA. Consistently in humans, germline mutations within the conserved MFCS1 element cause congenital limb malformations characterized by preaxial polydactyly (Lettice et al. 2003). Interestingly, the MFCS1 sequence is not conserved in limbless vertebrates such as snake, limbless lizard, and newt (Sagai et al. 2005). Although the SBE2-4 and MFCS1 elements are physically far from Shh, the TSS of the region upstream of Shh contains very few genes, and only one well-described TSS exists between the MFCS1 and the TSS of Shh (Fig. 3). Given the diverse expression pattern of Shh, it is likely that a number of other enhancer-elements remain to be identified in this "gene-poor" region.

Although many enhancers that drive Shh expression have been identified, very little is known about the specific transcription factors that control their activity. The temporal and spatial expression pattern of FoxA2 suggests that it could induce Shh expression (Chang et al. 1997; Epstein et al. 1999) in the midline. Consistently, conserved binding sites for FoxA2 and $\mathrm{Nkx} 6$ are required for SFPE2 activity (Jeong and Epstein 2003). The Nkx2.1 homeodomain protein has also been suggested as a likely candidate regulating Shh expression in ventral forebrain (Jeong et al. 2006).

No known consensus binding sites for transcription factors are affected by the mutations in the MFCS1 limb enhancer, and the mutations are not clustered close together. However, the severity of the polydactyly phenotype correlates negatively with the conservation of nucleotide at the mutation sites, suggesting that MFCS1 activity is controlled by conserved transcriptional regulators whose DNA-binding specificity is currently not known.

\section{Hh processing and secretion}

After translation, Hh undergoes multiple processing steps that are required for generation and release of the active ligand from the producing cell. The mechanisms involved in Hh processing and secretion are evolutionarily conserved (see Burke et al. 1999; Amanai and Jiang 2001; Chamoun et al. 2001; Ingham and McMahon 2001; Caspary et al. 2002; Dai et al. 2002; Ma et al. 2002).

After the signal sequence is removed, the Hh molecule undergoes a cleavage catalyzed by its own C-terminal domain that occurs between conserved glycine and cysteine residues (Fig. 4; Lee et al. 1994; Porter et al. 1996). First, the peptide bond between these residues is rearranged to form a thioester. Subsequently, a hydroxyloxygen of cholesterol attacks the carbonyl of the thioester, displacing the sulfur and cleaving the Hh protein into two parts, a C-terminal processing domain with no known signaling activity and an $\mathrm{N}$-terminal $\mathrm{Hh}$ signaling domain $(\mathrm{HhN})$ of $\sim 19 \mathrm{kDa}$ that contains an esterlinked cholesterol at its C terminus (Porter et al. 1996). The cholesterol modification results in the association of $\mathrm{HhN}$ with the plasma membrane. Subsequently, a palmitic acid moiety (Pepinsky et al. 1998) that is required for $\mathrm{HhN}$ activity is added to $\mathrm{N}$ terminus of $\mathrm{Hh}$ by the acyltransferase Skinny hedgehog (Ski, HHAT in humans) (Chamoun et al. 2001; Lee et al. 2001; Buglino and Resh 2008). The resulting fully active $\mathrm{HhN}$ signaling molecule is thus modified by cholesterol at its $\mathrm{C}$ terminus and palmitate at its $\mathrm{N}$ terminus (Chamoun et al. 2001; Lee 


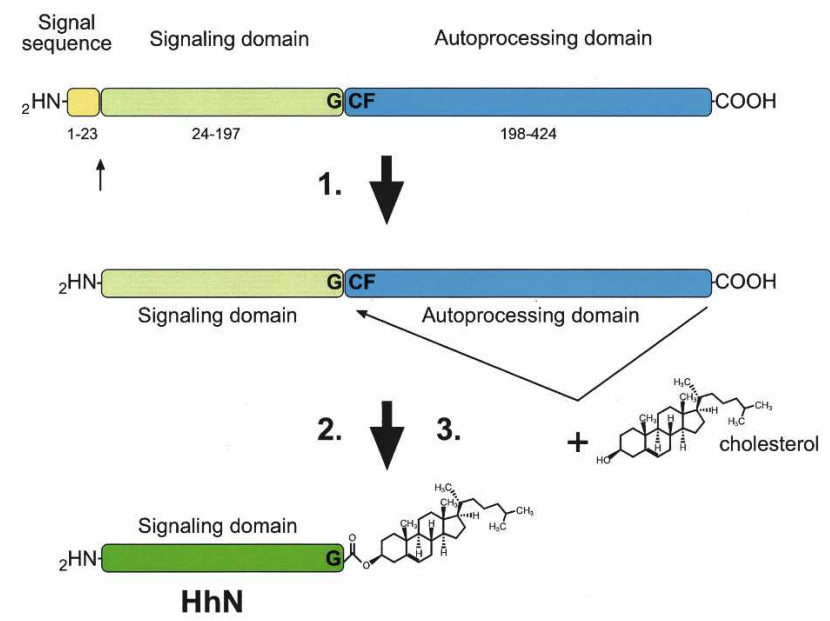

4. 2 Ski (acyltransferase) +

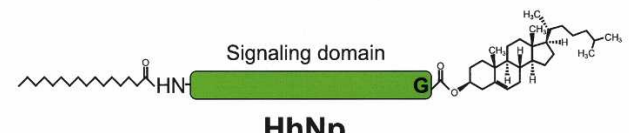

HhNp

Figure 4. (A) Hedgehog protein maturation. Hh protein undergoes multiple processing steps: (1) the signal sequence is cleaved; (2) the C-terminal domain of the Hh polypeptide catalyzes an intramolecular cholesteroyl transfer reaction, resulting in (3) the formation of a C-terminally cholesterol-modified $\mathrm{N}$ terminal Hh signaling domain $(\mathrm{HhN})$. This causes association of HhN with membranes, which facilitates the final modification step 4 , the addition of a palmitic acid moiety to the $\mathrm{N}$ terminus by the acyltransferase Skinny hedgehog, resulting in the formation of dually modified $\mathrm{Hh}$ signaling domain $(\mathrm{HhNp})$.

and Treisman 2001). For clarity, we refer to this protein as Hh hereafter.

\section{Formation of the Hh gradient}

Although Hh is tightly associated with the plasma membrane, it is able to act directly over a long range (Roelink et al. 1995; Briscoe et al. 2001; Wijgerde et al. 2002). In both Drosophila and vertebrates, the secretion of $\mathrm{Hh}$ from the producing cell requires the activity of the 12span transmembrane protein, Dispatched (Disp). Disp, like Ptc, belongs to the bacterial RND (Resistance-Nodulation-Division) family of transport proteins. Loss of Disp leads to accumulation of $\mathrm{Hh}$ in the producing cells and failure of long-range signaling (Burke et al. 1999; Ma et al. 2002).

Distances over which Hh has been shown to act are $\sim 50 \mu \mathrm{m}$ in Drosophila wing imaginal disc and $\sim 300 \mu \mathrm{m}$ in vertebrate limb bud (Zhu and Scott 2004). How Hh moves over a such a long distance is still not clear, and could involve passive diffusion, active transport, and/or transcytosis. Genetic evidence points to a role of heparan sulfate proteoglycans in this process, as $\mathrm{Hh}$ cannot be transported across a field of cells lacking the heparan sulfate synthesizing enzymes of the EXT/tout velu (ttv)/ brother of tout velu (botv)/sister of tout velu (sotv) family (Bellaiche et al. 1998; Lin et al. 2000; Bornemann et al. 2004; Han et al. 2004a; Koziel et al. 2004). The substrates of ttv involved in this process appear to be the glypicans (glycosylphosphatidylinositol-linked HSPGs) Dally and Dally-like (Han et al. 2004b). Dally and Dallylike also affect $\mathrm{Hh}$ signaling by facilitating binding of $\mathrm{Hh}$ to cell surfaces (Nakato et al. 1995; Lum et al. 2003a; Han et al. 2004b).

Whether $\mathrm{Hh}$ is transported as individual molecules or assembled into larger particles prior to transport is not clear. Several lines of evidence support the role of large lipid/protein particles in long-range Hh transport. First, Hh staining of receiving cells displays a punctate pattern (Panakova et al. 2005). In addition, soluble Shh multimers that contain lipids and that have strong signaling potency have been described in mammalian cells (Zeng et al. 2001), and it has been reported that Drosophila $\mathrm{Hh}$ is transported in lipoprotein particles (Panakova et al. 2005; Callejo et al. 2006). Recent genetic evidence also suggests that Hh may be secreted in two different forms, the first of which diffuses poorly and acts at a short range. The second form is "packaged" for longrange transport, and its formation requires the cytoplasmic membrane-scaffolding protein Reggie-1/flotillin-2 (Katanaev et al. 2008).

Multiple studies have analyzed the role of cholesterol modification in $\mathrm{Hh}$ transport in vivo, with conflicting results suggesting that cholesterol either aids or hinders Hh transport (for example, see Lewis et al. 2001; Dawber et al. 2005; Gallet et al. 2006; Li et al. 2006). These studies are complicated because the protein expression levels of the different mutant forms of Hh need to be constant in order to rule out dose effects. In addition, interpretation of the results is made even more difficult by the fact that $\mathrm{Hh}$ protein lacking cholesterol modification is soluble, and thus its secretion does not require Dispatched and it can escape the producing cell without being palmitoylated (Mann and Beachy 2004) and could even become palmitoylated later during transport or at the receiving cell. Thus, genetic experiments alone cannot conclusively determine the role of cholesterol modification in $\mathrm{Hh}$ activity and transport. In contrast, analysis of the role of the palmitate modification in Hh transport is more straightforward, as palmitoylation can be selectively prevented either by mutation of Ski, or mutation of the palmitoylated $\mathrm{N}$-terminal cysteine of the Hh proteins. Such experiments indicate that palmitoylation is required for Hh activity in Drosophila (Burke et al. 1999), and for generation of soluble multimeric $\mathrm{Hh}$ protein complexes and long-range signaling in vertebrates (Chen et al. 2004).

Several mechanisms are used to control the shape and size of the Hh gradient (for review, see Teleman et al. 2001). Very high levels of Hh can induce Hh expression in responding cells both in Drosophila and in mammals (Tabata et al. 1992; Roelink et al. 1995; Methot and Basler 1999). This increases the local concentration of 
Hh near the original source. Hh also induces the expression of its receptor Ptc, which internalizes Hh and targets it to the lysosomes for degradation (Chen and Struhl 1996; Incardona et al. 2000; Gallet and Therond 2005). This negative feedback loop restricts the spreading of the Hh signal through tissues. Vertebrates also have an additional transmembrane protein, Hedgehog-interacting protein (HIP), which is also induced by Hh signaling and binds to and further reduces the range of movement of Hh (Chuang and McMahon 1999; Jeong and McMahon 2005).

\section{Hh signal transduction}

\section{Hh receptor}

In addition to the glypical dally-like, which acts both in Hh transport and as an accessory receptor, the binding of Hh to responding cells is facilitated by the transmembrane proteins Cdo and Boc (iHog and boi in Drosophila) (Lum et al. 2003a; Tenzen et al. 2006; Yao et al. 2006). These proteins act positively in the pathway, binding to Hh via conserved fibronectin repeats (Yao et al. 2006) and increasing $\mathrm{Hh}$ association with its signaling receptor Ptc (Tenzen et al. 2006; Yao et al. 2006). The expression levels of Cdo and Boc are down-regulated in response to Hh signaling, resulting in yet another negative feedback that limits pathway activity (Fig. 1C).

In the absence of Hh ligand, Ptc catalytically inhibits the activity of the seven-transmembrane-span receptorlike protein Smo (Taipale et al. 2002). Binding of Hh to Ptc results in loss of Ptc activity, and consequent activation of Smo. Smo then transduces the Hh signal to the cytoplasm (Stone et al. 1996; Taipale et al. 2002). This general model is based on the genetic observations that loss of Hh or Smo cause similar phenotypes, and that Ptc loss results in a phenotype that is similar to strong overexpression of Hh. Epistasis analyses in turn indicate that Ptc acts downstream from $\mathrm{Hh}$ and upstream of or parallel to Smo (Ingham et al. 1991; Alcedo et al. 1996; van den Heuvel and Ingham 1996). Binding of Hh to Ptc, in turn, was determined using purified Shh and cultured cells overexpressing Ptc (Stone et al. 1996; Fuse et al. 1999).

By inferring the protein levels of ligand-bound and unbound Ptc from gene expression, Casali and Struhl (2004) suggested that the activity of the pathway depends on the ratio between these two forms. However, the fact that increasing the level of Ptc protein decreases cellular responsiveness to Hh (see Bailey et al. 2002; Taipale et al. 2002) indicates that it is the absolute amount of unliganded Ptc in a cell that controls pathway activity. This mechanism, together with the induction of Ptc by Hh results in gradual desensitization of cells to $\mathrm{Hh}$ and allows cells to accurately interpret the wide range of $\mathrm{Hh}$ concentrations present in morphogenetic gradients.

In vertebrates, Ptc exists as two isoforms, Ptc and Ptc2. Mice deficient in Ptc2 are viable, but develop alopecia and epidermal hypoplasia and have increased tumor incidence in the presence of one mutant allele of Ptc (Lee et al. 2006; Nieuwenhuis et al. 2006). Loss of Ptc, in turn, results in complete activation of the Hh pathway (Goodrich et al. 1997), suggesting that Ptc is the functional ortholog of Drosophila Ptc. Ptc has been proposed to function as a permease to affect the transmembrane movement and/or concentration of small molecules that then either agonize or antagonize Smo (Taipale et al. 2002). Supporting this hypothesis, Smo activity can be modulated by many synthetic small molecules (Chen et al. 2002b; Frank-Kamenetsky et al. 2002) and natural products, including the steroidal alkaloids cyclopamine and jervine (Chen et al. 2002a). These compounds were identified by Keeler and Binns (1966) as active ingredients in Veratrum californicum, a plant whose ingestion by sheep led to an outbreak of cyclopia in US midwest in the 1950s. The clue that these compounds antagonize Shh signaling came from the observation that the stillborn lambs have a phenotype that is strikingly similar to that of Shh mutant mouse embryos (Chiang et al. 1996).

The structural similarity between cyclopamine and sterols (Cooper et al. 1998) suggests that endogenous sterols might regulate Smo activity. This hypothesis is also supported by genetic evidence, as disruption of embryonic cholesterol synthesis leads to developmental malformations that strikingly mimic Hh mutants (Kelley et al. 1996; Cooper et al. 1998). Oxysterols (Corcoran and Scott 2006) and vitamin D3 derivatives (Bijlsma et al. 2006) have been suggested to be the endogenous metabolites that modulate Smo activity. Of these, vitamin D3 appears to bind to Smo (Bijlsma et al. 2006) based on its ability to compete against binding of labeled cyclopamine (Chen et al. 2002a).

Based on the fact that increased activity of oncogenically activated Smo proteins correlates with their increased resistance to cyclopamine, it was suggested that Smo exists in active and inactive conformational states (Taipale et al. 2000). Similarly, experiments in Drosophila suggest that dSmo can exist in two conformational states (Zhao et al. 2007). However, the activity of all small molecules found to activate or inhibit Smo appear to be specific for vertebrate Smo proteins, suggesting that mechanisms of action of Drosophila and mammalian Smo may be different. Stronger evidence for this comes from both structural and functional analyses, which indicate that Smo C-terminal domain has evolved differentially in vertebrates and invertebrates.

Several lines of evidence suggest that the cytoplasmic components and the mechanism of Hh signal transduction have diverged between Drosophila and mammals. In the following section, we will first discuss the mechanism of intracellular Hh signal transduction in Drosophila, which is fairly well understood. We will then discuss the evidence suggesting that Drosophila and mammals appear to use different components and mechanisms in transducing the Hh signal between Smo and the Ci/GLI transcription factors.

\section{Intracellular Hh signaling in Drosophila}

In the absence of Hh, Ptc keeps Drosophila Smo in an unphosphorylated state. Unphosphorylated Smo is 
cleared from the cell surface via endocytosis and is degraded in lysosomes (Jia et al. 2004; Zhang et al. 2004). After Hh stimulation, Smo is hyperphosphorylated and its endocytosis and degradation are blocked. Phosphorylation can be mimicked by mutation of the phosphorylation sites to negatively charged residues or by mutating adjacent positively charged arginine clusters to alanine. Based on these observations, Zhao et al. (2007) suggested that phosphorylation neutralizes the positive charge of the dSmo $\mathrm{C}$ terminus and induces a conformational switch in the C-terminal cytoplasmic tail and consequent dimerization or multimerization of dSmo. How these events lead to activation of downstream signaling pathway components is not understood (Zhao et al. 2007).

dSmo C terminus binds directly to the kinesin-like protein Cos2, which acts as a scaffolding protein, bringing together multiple cytoplasmic components of the pathway (Jia et al. 2003; Lum et al. 2003b; Ogden et al. 2003; Ruel et al. 2003). These include the full-length transcriptional activator form of Ci, CiA (155 kDa) (Robbins et al. 1997), and multiple serine-threonine kinases, including a kinase that specifically acts on the Hh pathaway, Fused (Fu) (Therond et al. 1996) and the multifunction kinases PKA, GSK3 $\beta, \mathrm{CKI} \alpha$, and CKI $\varepsilon$ (for review, see Aikin et al. 2008).

In the absence of $\mathrm{Hh}, \mathrm{CiA}$ is hyperphosphorylated by the combined action of PKA, which acts as a priming kinase, and GSK $3 \beta$ and the casein kinases, which further phosphorylate the primed substrate (Fig. 1B). The hyperphosphorylation promotes recognition of CiA by the ubiquitin E3 ligase Slimb ( $\beta$-TrCP in vertebrates) (Jiang and Struhl 1998), leading to the generation of a truncated transcriptional repressor form of $\mathrm{Ci}, \mathrm{CiR}$ (75 kDa) (Y. Chen et al. 1999; Price and Kalderon 1999, 2002; Wang et al. 1999; Jia et al. 2002, 2005). In addition to promoting CiR formation, Cos 2 regulates $\mathrm{Ci}$ by tethering it to the cytoplasm and preventing its nuclear translocation (C.H. Chen et al. 1999; G. Wang et al. 2000).

In the presence of $\mathrm{Hh}$, Sno accumulates and the binding of Cos2 to Smo prevents conversion of CiA to CiR (Hooper 2003; Jia et al. 2003). However, this mechanism alone is not sufficient to fully activate the pathway, as some CiA is still retained in the cytoplasm by another protein, Supressor of Fused [Su(Fu)] (Pham et al. 1995; Methot and Basler 2000). Genetic evidence from Drosophila indicates that full activation of the pathway in response to $\mathrm{Hh}$ requires the $\mathrm{Fu}$ protein kinase, which blocks the negative influence of $\mathrm{Su}(\mathrm{Fu})$ on $\mathrm{Ci}$ (Ohlmeyer and Kalderon 1998; Lefers et al. 2001; Lum et al. 2003b). Upon entering the nucleus, CiA binds to specific sequences (Kinzler and Vogelstein 1990; Hallikas et al. 2006) in promoter and enhancer regions and controls the transcription of the Hh target gene(s).

In Drosophila, cellular responsiveness to $\mathrm{Hh}$ is controlled by modulating the expression of $\mathrm{Ci}$. In the posterior compartment of the wing disc, $\mathrm{Hh}$ and its receptor components are expressed, but target genes are not activated, as Ci mRNA expression is repressed by Engrailed (Eaton and Kornberg 1990). Cells posterior to the morphogenetic furrow of Drosophila eye, in turn, fail to re- spond to $\mathrm{Hh}$ because $\mathrm{Ci}$ levels are post-transcriptionally down-regulated due to the expression of hib (Hh-induced MATH and BTB protein; SPOP in vertebrates), a protein that acts as a substrate recognition subunit for the Cul3 E3 ubiquitin ligase. In contrast to Slimb-mediated ubiquitinylation, which leads to partial Ci degradation, the hib/Cul3-mediated ubiquitinylation causes complete degradation of Ci (L. Zhang et al. 2006). Expression of hib increases in response to $\mathrm{Hh}$, providing another negative feedback mechanism to this pathway (Fig. 1C; Kent et al. 2006; Q. Zhang et al. 2006).

\section{Divergence of pathway components and mechanisms}

Despite the conservation of the Hh signaling pathway and many of its roles in development between invertebrate and vertebrate species (Ingham and McMahon 2001; Taipale and Beachy 2001), the mechanisms by which Smo regulates the Ci/GLI transcription factors appears to be distinct between Drosophila and mammals (Huangfu and Anderson 2006; Varjosalo and Taipale 2007).

The relatively rapid evolution of some components of the Hh pathway, including $\mathrm{Smo}, \mathrm{Cos} 2$, and $\mathrm{Fu}$, is apparent at sequence level. The C-terminal domains of vertebrate Smo proteins are significantly shorter than those of invertebrates and lack the main phosphorylation regions described below. In addition, the two mammalian orthologs of Cos2, Kif27, and Kif7 have none of the unique sequence characteristics of Cos2 that differentiate Cos2 from the kinesin family of motor proteins. Based on sequence, Kif7 and Kif27 appear to be functional molecular motors, whereas Cos2 has apparently lost its ability to bind ATP and function as a motor protein. The closest mammalian homolog of Drosophila Fu is also highly diverged, and significant homology between these proteins can be seen only in the protein kinase domain itself (Murone et al. 2000).

Drosophila Smo activation is coupled to the hyperphosphorylation of 26 serine/threonine residues located within the C-terminal cytoplasmic tail by PKA and CKI (Jia et al. 2004; Zhang et al. 2004; Apionishev et al. 2005). None of these PKA or CKI phosphorylation sites are conserved in vertebrate Smo. The vertebrate Smo C termini lacks one of the two known Cos2-binding domains (Jia et al. 2003), and the region homologous to the other domain (Lum et al. 2003b) is dispensable for mouse Smo (mSmo) function (Varjosalo et al. 2006). Drosophila Cos2, or mouse Kif7 or Kif27 do not appear to bind to mSmo or GLI proteins or affect Shh signaling when overexpressed in NIH-3T3 cells (Varjosalo et al. 2006). Furthermore, loss of the Fu protein kinase-which forms a tight complex with Cos 2 and is required for Hh signaling in Drosophila-appears not to impair $\mathrm{Hh}$ signaling in mice (Chen et al. 2005; Merchant et al. 2005). Taken together, this evidence suggests that the Cos2-Fu complex, which is centrally important in Drosophila, plays little or no role in mammalian Hh signaling. Instead, it appears that mammalian $\mathrm{Hh}$ signaling critically depends on $\mathrm{Su}(\mathrm{Fu})$ (Svard et al. 2006) — which has a minor role in Drosophila 
(Ohlmeyer and Kalderon 1998)-and on several components involved in formation of the primary cilia, which either do not have Drosophila orthologs or whose orthologs appear not to function on the Drosophila $\mathrm{Hh}$ pathway (Nybakken et al. 2005).

Primary cilium is an organelle that protrudes from the surface of most vertebrate cells. Genetic evidence suggesting a role for primary cilium in mammalian Hh signaling comes from studies that found that mutations of several proteins required for its formation, including Kif3a, Ift88, and Ift172, result in embryonic phenotypes characteristic of the loss of Shh signaling (Huangfu et al. 2003; Park et al. 2006; Caspary et al. 2007; Vierkotten et al. 2007). Subsequent studies have linked these proteins to the processing of the GLI transcription factors (May et al. 2005; Caspary et al. 2007). Some experiments suggest that primary cilium would act as a "signaling center" where the biochemical events of signal transduction take place. It has been reported that activated mammalian Smo accumulates to primary cilia in response to Shh treatment (Corbit et al. 2005); in the absence of Shh, this accumulation is prevented by Ptc (Rohatgi et al. 2007). Other components involved in Hh signaling, including $\mathrm{Su}(\mathrm{Fu})$ and unprocessed GLI proteins, have also been localized to the primary cilium (Haycraft et al. 2005).

Drosophila lacking centrioles, and all microtubulebased structures derived from them, including centrosomes, cilia, and flagella develop almost normally, indicating that cilia are not required for Drosophila Hh signaling (Basto et al. 2006). In contrast, the genetic studies described above have clearly established that mammalian Hh signaling depends on a process that requires components involved in formation of primary cilia. However, this evidence is also consistent with a model where some other microtubule-linked process that is critical for Hh signaling is disrupted by loss of these proteins. In addition, the fraction of cellular Hh pathway components found in the primary cilium at any given time appears small. Thus, it remains to be established what role cilia play in mammalian Hh signaling and whether localization of the pathway components to cilia is required for signaling.

The lack of effect of the closest mammalian homolog of Drosophila Fused on Hh signaling suggests that other-mammalian-specific_kinases act on this pathway. We recently identified two such kinases, DYRK2 and MAP3K10, which are required for Shh signaling in NIH-3T3 cells (Varjosalo et al. 2008). Of these, DYRK2 directly phosphorylates GLI2 and GLI3 and induces their degradation. MAP3K10, in turn, appears to act in a more indirect fashion, binding to and phosphorylating multiple other proteins that regulate the Hh pathway, including GSK3 $\beta$, DYRK2, and Kif3a (Nagata et al. 1998; Varjosalo et al. 2008). Because of the many connections of MAP3K10 to different pathway components, its mechanism of action is likely to be complex, and requires further study. In addition to DYRK2 and MAP3K10, it has been reported that other vertebratespecific kinases regulate Shh signaling. These include protein kinase $\mathrm{C}-\delta(\mathrm{PKC} \delta)$, mitogen-activated protein/ex- tracellular signal-regulated kinase-1 (MEK-1), Akt, and DYRK1 (Mao et al. 2002; Riobo et al. 2006a,b). From our studies and previous analyses of the Hh pathway, it appears that Hh does not regulate the activity of any known kinase toward a generic substrate. Thus, the mechanism by which Hh signal is transduced appears not to depend on activation of pathway-specific kinases, but on regulation of access of substrates to relatively generic multifunctional kinases.

In conclusion, the mechanisms of mammalian Hh signaling have clearly diverged from those of Drosophila. This suggests that even signal-transduction mechanisms of conserved signaling pathways have not been "locked" early in evolution, and that they can be subject to evolutionary change. The divergence of the Hh pathwayarguably the last major signaling pathway to evolve-is also relevant to the evolution of multicomponent signaling pathways. Some pathways, such as the Notch pathway, where the same protein (Notch) functions as a receptor and a transcriptional coactivator are relatively simple and consist of a small number of pathway-specific components (Artavanis-Tsakonas et al. 1999; PiresdaSilva and Sommer 2003). Other pathways, such as the Hh signaling pathway in Drosophila are more complex. In addition to many multifunctional proteins, the $\mathrm{Hh}$ pathway consists of 11 known specific components: Hh, Skinny hedgehog (Ski), Dispatched, iHog/boi, Ptc, Smo, $\mathrm{Cos} 2, \mathrm{Fu}, \mathrm{Su}(\mathrm{Fu})$, and $\mathrm{Ci}$ (Burke et al. 1999; Chamoun et al. 2001; Lum and Beachy 2004). The emergence of the Cos2-Fu system in invertebrates suggests that such multicomponent pathways may evolve by insertion of novel proteins between existing pathway components.

\section{Regulation of GLI activity}

In contrast to the differences in signaling between Smo and GLI, the activities of the GLI proteins themselves are regulated similarly to $\mathrm{Ci}-$ with the added complexity that the activator and repressor functions of $\mathrm{Ci}$ are divided in mammals to three GLI proteins, GLI1-3 (Jacob and Briscoe 2003; Ruiz i Altaba et al. 2007). GLI1 and GLI2 are responsible for most activator functions and have similar activities at protein level (Bai and Joyner 2001). Whereas loss of GLI2 is embryonic lethal (Mo et al. 1997; Ding et al. 1998; Matise et al. 1998), GLI1 is dispensable for normal development (Park et al. 2000). GLI1 expression is induced by Hh ligands, and its function appears to be primarily to provide positive feedback and to prolong cellular responses to Hh. GLI3, in turn, functions primarily as a repressor (B. Wang et al. 2000; Litingtung et al. 2002), and its loss or mutation leads to limb malformations in mice and humans (Vortkamp et al. 1991; Schimmang et al. 1992).

GLI activity appears to be regulated by $\mathrm{Hh}$ in a way that is very similar to that observed in Drosophila. In the absence of Hh, GLI3 is phosphorylated, recognized by $\beta-\operatorname{TrCP}$, and proteolytically processed to a truncated repressor form (B. Wang et al. 2000; Pan et al. 2006). Whether similar processing of GLI2 results in complete degradation or generation of a truncated repressor form is 
unclear (Pan et al. 2006; Wang and Li 2006). Addition of Shh leads to inhibition of processing and accumulation of full-length forms of both GLI2 and GLI3.

\section{Dose-, time-, and context-dependent responses to $\mathrm{Hh}$}

The developmental processes that the Drosophila and vertebrate Hh signaling pathways regulate appear remarkably conserved (Ingham and McMahon 2001). At the cellular level, the effects of Hh range from growth and self-renewal to cell survival (Liu et al. 1998; Rowitch et al. 1999), differentiation, and/or migration. During embryogenesis, the Hh cascade is used repeatedly and in different tissues to induce a large number of developmental processes. The ability of a single morphogen to affect almost every part of the vertebrate body plan is made possible by the fact that cellular responses to $\mathrm{Hh}$ depend on the type of responding cell, the dose of $\mathrm{Hh}$ received, and the time the cell is exposed to $\mathrm{Hh}$ (see below). At the molecular level, the diverse cellular responses are effected by induction of different sets of target genes. Among the genes regulated tissue specifically by Hh signaling are those encoding other secreted signaling proteins, including bone morphogenetic protein 4 (BMP4) (Astorga and Carlsson 2007), fibroblast growth factor 4 (FGF4) (Laufer et al. 1994), and vascular endothelial growth factor (VEGF)-A (Pola et al. 2001), genes involved in cell growth and division (e.g., $N$-Myc) (Oliver et al. 2003), and many transcription factors that are essential for animal development, including members of the Myod/Myf, Pax, Nkx, Dbx, and Irx families (Pierani et al. 1999; Gustafsson et al. 2002; Jacob and Briscoe 2003; Vokes et al. 2007). The total number of genes that Hh regulates is only beginning to be discovered: A number of expression profiling studies have identified several novel target genes (for example, see Xu et al. 2006; Vokes et al. 2007), and our genome-wide in silico analyses identified 42 conserved enhancer modules with two or more GLI sites in the human genome (Hallikas et al. 2006).

The genes that are induced by Hh in many tissues, in turn, are generally involved in positive and negative feedback to the pathway itself and include Hib, GLI1, Ptc, and HIP (Fig. 1C). As Ci and the GLI proteins act as repressors in the absence of $\mathrm{Hh}$ and activators in its presence, many of the target genes also behave similarly, being repressed in the absence of $\mathrm{Hh}$ and induced in its presence.

\section{Hh acts both directly and indirectly to pattern tissues}

During the development of the Drosophila wing imaginal disc, posterior $(\mathrm{P})$ compartment cells express and secrete the Hh protein (Fig. 5A). The secreted Hh then induces the expression of target genes in cells located in the anterior (A) compartment. Hh acts both directly at intermediate range to pattern the anterior wing tissues close to the A-P boundary and indirectly over long range by inducing the BMP family morphogen decapentaplegic (dpp) (Basler and Struhl 1994; Tabata and Kornberg 1994). Dpp diffuses bidirectionally into both A and P compart-
A

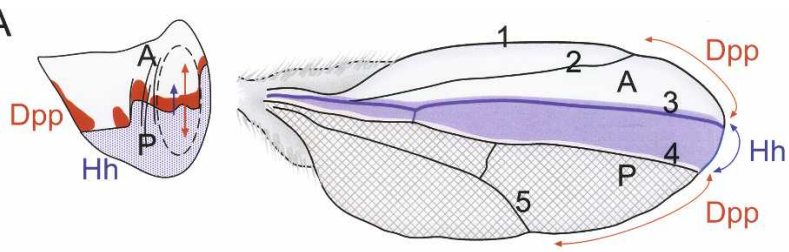

B
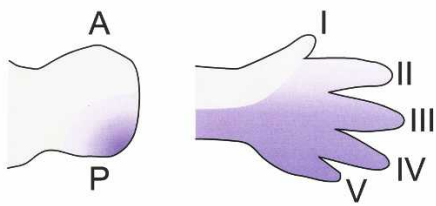

C

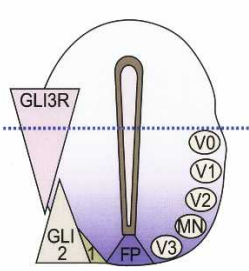

Figure 5. (A) Hh acts both directly and indirectly to pattern the Drosophila wing imaginal disc. (Left) Hh activates decapentaplegic (dpp; red) at the anterior side of the A-P boundary of the imaginal disc, which diffuses into and patterns both $\mathrm{A}$ and $\mathrm{P}$ compartments (red arrow). Hh (blue) also acts directly to pattern the anterior compartment close to the A-P boundary. (Right) Adult wing showing the regions derived from the anterior $(\mathrm{A}$, top) and posterior compartment ( $\mathrm{P}$, bottom, shaded), and the regions patterned by Dpp (red arrows) and Hh (blue color, between wing veins 3 and 4). (B) Shh has a similar role in anteriorposterior patterning of the distal elements of vertebrate limbs and in specifying digit identity (roman numerals). (C) Time and dose-dependent action of Shh. The gradient of Shh (blue color) emanating from the notochord (not shown) and floor plate (FP) progressively defines five different neuronal subtypes in the ventral neural tube. The Shh protein gradient is converted to gradient of GLI activities shown on the left. GLI1 and GLI2 (bottom) act as transcriptional activators, whereas GLI3 functions as a repressor (GLI3R, top). (MN) Motoneuron; (V0-V3) interneurons. Dotted line indicates the dorsal limit of the domain patterned by the Shh gradient. Data adapted from Fuccillo et al. (2006).

ments and controls the growth and patterning of the entire wing. Dpp expression is normally repressed by $\mathrm{CiR}$, and its activation only requires that this repression is lifted. Therefore, very low levels of Hh suffice to induce dpp expression (Methot and Basler 1999). The short and intermediate range effects of $\mathrm{Hh}$ require induction of target genes such as collier (col) and engrailed (en), whose expression require $\mathrm{CiA}$ function and higher levels of $\mathrm{Hh}$ (Methot and Basler 1999; Hooper 2003).

Shh has an analogous role in controlling vertebrate limb patterning. Shh expressed by the ZPA located at the posterior margin of developing limb buds diffuses to adjacent tissues, forming a temporal and spatial gradient that specifies the anterior-posterior pattern of the limbs (Fig. 5B).

\section{Time and dose dependency of the $\mathrm{Hh}$ response}

The effect of Hh dose on target tissue responses is best characterized in the specification of cell identities in the ventral neural tube (Jessell 2000; Patten and Placzek 2000; Marti and Bovolenta 2002). During neural tube de- 
velopment, Shh protein diffuses from the notochord and floor plate, creating a concentration gradient across the ventral neural tube (Fig. 5C). Different doses of Shh within this gradient specify five neuronal subtypes at precise positions along the floor plate-roof plate axis. Initially, Shh induces Class II homeodomain (e.g., Nkx2.2, Nkx6.1) (Pierani et al. 1999; Jacob and Briscoe 2003) and represses Class I homeodomain (Pax6, Pax7, Irx3, and Dbx1/2) transcription factors. Cross-repressive interactions between these factors then act to sharpen the expression boundaries and to subsequently direct cells to differentiate into specific lineages (Briscoe and Ericson 2001).

The activity of Shh as a morphogen was initially thought to be due to concentration-dependent responses, but the duration of Shh signal seems also to critically affect cellular responses. Both during neural tube and limb development, the pattern of cellular differentiation is controlled not only by the amount but also by the time of Shh exposure (Briscoe and Ericson 2001; Ahn and Joyner 2004; Harfe et al. 2004). The changing of the concentration or duration of Shh seem to have an equivalent effect on intracellular signaling.

Chick neural cells convert different concentrations of Shh into time-limited periods of signal transduction, such that signal duration is proportional to Shh concentration (Dessaud et al. 2007). This depends on the gradual desensitization of cells to Shh caused by up-regulation of patched (Ptc) (Taipale et al. 2002). Thus, in addition to its role in shaping the Shh gradient (Chen and Struhl 1996; Briscoe et al. 2001; Jeong and McMahon 2005), Ptc participates cell-autonomously in gradient sensing. This mechanism integrates Shh signal strength over time, allowing cells to more accurately determine their distance from the Hh source-resulting in more robust patterning of the nervous system.

\section{Role of Hh signaling in young and adult mammals}

The multiple roles of Hh signaling in embryonic patterning are discussed above and reviewed in more detail in McMahon et al. (2003). Much less is known about the roles played by Hh in pupal development and in maintaining homeostasis of tissues during adult life.

During maturation of mouse pups, Ihh signaling is important for bone growth. Permanent deletion of $I h h$ in chondrocytes of mice carrying conditional and inducible null alleles of Ihh results in permanent defects in bone growth, inhibiting proliferation and promoting differentiation of chondrocytes, leading to dramatic expansion of the hypertrophic zone (Razzaque et al. 2005; Maeda et al. 2007) and truncation of long bones. Interestingly, similar phenotype was observed with treatment of young mice with Smo antagonist for just $48 \mathrm{~h}$ (Kimura et al. 2008). In adults, Hh pathway controls bone homeostasis; activation of the Hh pathway in osteoblasts leads to bone resorption, and conversely, Hh inhibition protects aging mice against bone loss (Mak et al. 2008; Ohba et al. 2008). Adult mice seem to tolerate Hh antagonists well, suggesting that short-term Hh pathway inhibition might not interfere with the possible role of $\mathrm{Hh}$ as a stem cell factor (Berman et al. 2002; Kimura et al. 2008).

The best-characterized role for Hh signaling in adults is in the reproductive system, and Hh proteins are expressed and required for maturation of the germ cells in multiple species. In Drosophila ovary, Hh acts as a somatic stem cell factor, directly controlling the proliferation and maintenance of ovarian somatic stem cells (Zhang and Kalderon 2001). In mammals, Ihh and Dhh produced by granulosa cells act as paracrine factors to induce target gene expression in the developing theca cell compartment. This suggests that hedgehog signaling regulates the theca cell development in growing follicles (Wiigerde et al. 2005). Dhh also has a role in the regulating the development and function of the somatic cells of the testis (Bitgood et al. 1996; Yao et al. 2002).

\section{Aberrant Hh signaling in disease}

Loss of Hh signaling activity during vertebrate embryogenesis causes severe developmental disorders including holoprosencephaly, polydactyly, craniofacial defects, and skeletal malformations (Muenke and Beachy 2000; Hill et al. 2003; McMahon et al. 2003; L. Zhang et al. 2006). It is now also becoming evident that components required for the function of primary cilia are required in mammalian Shh signaling (Huangfu et al. 2003). It is therefore possible that Hh signaling may also be altered in human syndromes caused by defects in cilia, including Meckel, Bardet-Biedl and Kartagener syndromes, polycystic kidney disease, and retinal degeneration (Pan et al. 2005; Kyttala et al. 2006).

On the other hand, aberrant activation of Hh signaling can cause basal cell carcinoma (BCC, the most common type of skin cancer) (Hahn et al. 1996; Johnson et al. 1996), medulloblastoma (a childhood cancer with an invariably poor prognosis) (Goodrich et al. 1997; Berman et al. 2002), and rhabdomyosarcoma (Table 1; Kappler et al. 2004). These tumor types occur at an increased rate in patients or mice with germline mutations in Ptc, and sporadic cases are often associated with mutations in the Hh pathway components $\mathrm{Ptc}, \mathrm{Smo}$, or $\mathrm{Su}(\mathrm{Fu})$, or more rarely, the amplification of GLI1.

Aberrantly activated Shh signaling has also been suggested to play a role in other cancers, such as glioma, breast, esophageal, gastric, pancreatic, prostate, and small-cell lung carcinoma (see Table 1 for references). With the exception of rare GLI1 amplifications found in gliomas (Kinzler et al. 1987), the mutational basis of $\mathrm{Hh}$ pathway activation in these types of cancer has not been ascertained.

Multiple lines of evidence suggest that Hh acts to promote cancer by directly regulating cellular growth and/ or survival. Loss of one ptc allele causes larger body size in mice (Goodrich et al. 1997) and in humans (Gorlin 1987). Several common human single nucleotide polymorphisms affecting body height map close to Hh pathway components, including Ihh, Ptc, and Hip (Lettre et al. 2008; Weedon et al. 2008), suggesting that individual variation in height is determined in part by the strength 
Table 1. Cancers linked to aberrant Shh signaling

\begin{tabular}{|c|c|}
\hline Cancer type & References \\
\hline Basal cell carcinoma (BCC) & $\begin{array}{l}\text { (Hahn et al. 1996; } \\
\text { Johnson et al. 1996) }\end{array}$ \\
\hline Medulloblastoma & $\begin{array}{l}\text { (Goodrich et al. 1997; } \\
\text { Berman et al. 2002) }\end{array}$ \\
\hline Rhabdomyosarcoma & $\begin{array}{l}\text { (Hahn et al. 1996; } \\
\text { Kappler et al. 2004) }\end{array}$ \\
\hline Glioma & (Kinzler et al. 1987) \\
\hline Breast cancer & (Kubo et al. 2004) \\
\hline Esophageal cancer & $\begin{array}{l}\text { (Berman et al. 2003; } \\
\text { Watkins and Peacock 2004) }\end{array}$ \\
\hline Gastric cancer & (Berman et al. 2003) \\
\hline Pancreatic cancer & (Thayer et al. 2003) \\
\hline Prostate cancer & $\begin{array}{c}\text { (Karhadkar et al. 2004; } \\
\text { Sanchez et al. 2004) }\end{array}$ \\
\hline Small-cell lung cancer & (Watkins et al. 2003) \\
\hline Biliary tract cancer & (Berman et al. 2003) \\
\hline Bladder cancer & (Hamed et al. 2004) \\
\hline Oral cancer & (Nishimaki et al. 2004) \\
\hline
\end{tabular}

Mutations in Hh pathway components have been identified in BCC, medulloblastoma, rhabdomyosarcoma, and glioma (top).

of negative feedback loops that fine-tune Ihh signaling during bone growth. Hh pathway controls growth also during embryonic development-transgenic mice that overexpress ptc are consistently smaller than control mice, but remarkably well proportioned, illustrating that Hh signaling controls growth in many tissues. However, whether this growth effect is direct or indirectly caused by altered placental or vascular development is unclear.

In development of midbrain and forebrain, Shh is crucial in driving the rapid, extensive expansion of the early brain vesicles. The action of Shh is mediated through coordination of cell proliferation and survival (Britto et al. 2002). In addition, Shh has been implicated in regulating cell proliferation and survival in a number of other cell types, including retinal precursor cells (Jensen and Wallace 1997), myoblasts (Duprez et al. 1998), optic nerve astrocytes (Wallace and Raff 1999), cerebellar granule cells (Dahmane and Ruiz i Altaba 1999), and neural crest cells (Ahlgren and Bronner-Fraser 1999).

The molecular mechanisms by which Shh controls growth are beginning to be unraveled. In vitro studies have shown that the Shh protein up-regulates N-myc expression in cerebellar granule neuron progenitor (CGNP) cultures and that N-myc overexpression promotes CGNP proliferation even in the absence of Shh (Kenney et al. 2003). N-myc is thought to promote proliferation of CGNPs synergistically with cyclins D and $\mathrm{E}$ (Knoepfler et al. 2002), whose expression is also regulated by Shh (Duman-Scheel et al. 2002).

Direct evidence for the role of $\mathrm{N}$-myc in pathway-associated cancer comes from a study of Shh pathway-induced medulloblastoma formation in mice, where it was shown that the disruption of N-myc, but not c-myc, inhibits cellular proliferative responses to Shh (Hatton et al. 2006). This provides in vivo evidence that $\mathrm{N}$-myc plays a central role in Shh-mediated proliferation in
CGNPs and in medulloblastoma cells, which are thought to be derived from CGNPs (Hatton et al. 2006).

\section{Potential for therapeutic intervention}

As the Hh pathway in BCC and medulloblastoma is often affected at the level of Ptc or Smo, small molecule antagonists should act at/or downstream from these components (Taipale et al. 2000). Furthermore, several studies have shown that Smo can be targeted by small molecule drugs, and that antagonizing Smo could provide a way to interfere with tumorigenesis and tumor progression. The most commonly used antagonist of the Hh pathway is the plant alkaloid cyclopamine (Taipale et al. 2000). Cell-based high-throughput screening has revealed several distinct classes of antagonists, which, like cyclopamine, bind to Smo. These include SANTs 1-4 (Chen et al. 2002b); KAAD-cyclopamine (Taipale et al. 2000), compound-5 and compound-Z (Borzillo and Lippa 2005), and Cur-61414 (Frank-Kamenetsky et al. 2002). Although one phase I clinical trial has already reported promising results of $\mathrm{Hh}$ pathway antagonist in advanced BCC (Garber 2008), further clinical studies are needed to establish which of these antagonists are suitable for therapeutic use. As it has been proposed that autocrine Shh expression is required for growth of some cancers (Dahmane et al. 1997; Karhadkar et al. 2004), and stromal cell-derived Shh can also activate the Hh pathway in tumors (Becher et al. 2008), it might also be possible to treat tumors with Shh-specific monoclonal antibodies. In fact, one such antibody, $5 \mathrm{E} 1$, has been shown to block the growth of some tumors, including small-cell lung carcinoma (Watkins et al. 2003). In addition to targeting tumors that themselves have hyperactive $\mathrm{Hh}$ pathways, antagonists of the Hh pathway could also affect growth of tumors that use Hh ligands to induce angiogenesis (Pola et al. 2001; Nagase et al. 2008) or recruit other types of stromal cells supporting tumor growth. Further studies are needed to characterize the role that Shh plays in such tumor-host interactions.

Because adults can tolerate inhibition of the Hh pathway (Berman et al. 2002; Kimura et al. 2008), specifically blocking $\mathrm{Hh}$ signaling offers an effective treatment for the various cancers originating from aberrant Hh pathway activation. However, systemic treatment of pediatric tumors such as medulloblastoma may not be feasible due to the severe effects that transient inhibition of the Hh pathway has on bone growth (Kimura et al. 2008).

\section{Perspective}

The Hh signaling pathway was first identified in Drosophila $16 \mathrm{yr}$ ago. Subsequently, it has taken its rightful place among the major signaling pathways controlling animal development, being found to regulate the morphogenesis of a variety of tissues and organs during the development of organisms ranging from Drosophila to human (McMahon et al. 2003). In addition, the Hh pathway has been linked to multiple forms of human cancer, 
and the possibilities for therapeutic intervention are being actively pursued.

The synthesis and processing of the Hh ligand, its release and transport through tissues, and mechanisms of signal transduction in the receiving cells have been studied extensively. However, many aspects of Hh signaling remain incompletely understood. Further research is needed in multiple areas, including the study of $\mathrm{Hh}$ target gene responses, which is required to understand in detail how the graded $\mathrm{Hh}$ signals are converted to discrete cell-fate decisions, and to decipher the molecular mechanisms that underlie the exquisite specificity of cellular responses to $\mathrm{Hh}$. In addition, the therapeutic potential of Hh pathway agonists and antagonists in human degenerative diseases and cancer should be further investigated.

\section{Acknowledgments}

We thank Drs. Kirsi Sainio, Osamu Shimmi, Minna Taipale, and James Thompson for a critical review of the manuscript. This work was supported by the Academy of Finland and EU FP6 project Tumorhost Genomics.

\section{References}

Ahlgren, S.C. and Bronner-Fraser, M. 1999. Inhibition of sonic hedgehog signaling in vivo results in craniofacial neural crest cell death. Curr. Biol. 9: 1304-1314.

Ahn, S. and Joyner, A.L. 2004. Dynamic changes in the response of cells to positive hedgehog signaling during mouse limb patterning. Cell 118: 505-516.

Aikin, R.A., Ayers, K.L., and Therond, P.P. 2008. The role of kinases in the Hedgehog signalling pathway. EMBO Rep. 9: 330-336.

Alcedo, J., Ayzenzon, M., Von Ohlen, T., Noll, M., and Hooper, J.E. 1996. The Drosophila smoothened gene encodes a sevenpass membrane protein, a putative receptor for the hedgehog signal. Cell 86: 221-232.

Amanai, K. and Jiang, J. 2001. Distinct roles of Central missing and Dispatched in sending the Hedgehog signal. Development 128: 5119-5127.

Apionishev, S., Katanayeva, N.M., Marks, S.A., Kalderon, D., and Tomlinson, A. 2005. Drosophila Smoothened phosphorylation sites essential for Hedgehog signal transduction. Nat. Cell Biol. 7: 86-92.

Artavanis-Tsakonas, S., Rand, M.D., and Lake, R.J. 1999. Notch signaling: Cell fate control and signal integration in development. Science 284: 770-776.

Astorga, J. and Carlsson, P. 2007. Hedgehog induction of murine vasculogenesis is mediated by Foxf1 and Bmp4. Development 134: 3753-3761.

Bai, C.B. and Joyner, A.L. 2001. Glil can rescue the in vivo function of Gli2. Development 128: 5161-5172.

Bailey, E.C., Milenkovic, L., Scott, M.P., Collawn, J.F., and Johnson, R.L. 2002. Several PATCHED1 missense mutations display activity in patched1-deficient fibroblasts. $J$. Biol. Chem. 277: 33632-33640.

Basler, K. and Struhl, G. 1994. Compartment boundaries and the control of Drosophila limb pattern by hedgehog protein. $\mathrm{Na}$ ture 368: 208-214.

Basto, R., Lau, J., Vinogradova, T., Gardiol, A., Woods, C.G., Khodjakov, A., and Raff, J.W. 2006. Flies without centrioles.
Cell 125: 1375-1386.

Becher, O.J., Hambardzumyan, D., Fomchenko, E.I., Momota, H., Mainwaring, L., Bleau, A.M., Katz, A.M., Edgar, M., Kenney, A.M., Cordon-Cardo, C., et al. 2008. Gli activity correlates with tumor grade in platelet-derived growth factor-induced gliomas. Cancer Res. 68: 2241-2249.

Bellaiche, Y., The, I., and Perrimon, N. 1998. Tout-velu is a Drosophila homologue of the putative tumour suppressor EXT-1 and is needed for Hh diffusion. Nature 394: 85-88.

Berman, D.M., Karhadkar, S.S., Hallahan, A.R., Pritchard, J.I., Eberhart, C.G., Watkins, D.N., Chen, J.K., Cooper, M.K., Taipale, J., Olson, J.M., et al. 2002. Medulloblastoma growth inhibition by hedgehog pathway blockade. Science 297: 1559-1561.

Berman, D.M., Karhadkar, S.S., Maitra, A., Montes De Oca, R., Gerstenblith, M.R., Briggs, K., Parker, A.R., Shimada, Y., Eshleman, J.R., Watkins, D.N., et al. 2003. Widespread requirement for Hedgehog ligand stimulation in growth of digestive tract tumours. Nature 425: 846-851.

Berman, D.M., Desai, N., Wang, X., Karhadkar, S.S., Reynon, M., Abate-Shen, C., Beachy, P.A., and Shen, M.M. 2004. Roles for Hedgehog signaling in androgen production and prostate ductal morphogenesis. Dev. Biol. 267: 387-398.

Bijlsma, M.F., Spek, C.A., Zivkovic, D., van de Water, S., Rezaee, F., and Peppelenbosch, M.P. 2006. Repression of smoothened by patched-dependent (pro-)vitamin D3 secretion. PLoS Biol. 4: e232. doi: 10.1371/journal.pbio.0040232.

Bitgood, M.J., Shen, L., and McMahon, A.P. 1996. Sertoli cell signaling by Desert hedgehog regulates the male germline. Curr. Biol. 6: 298-304.

Bornemann, D.J., Duncan, J.E., Staatz, W., Selleck, S., and Warrior, R. 2004. Abrogation of heparan sulfate synthesis in Drosophila disrupts the Wingless, Hedgehog and Decapentaplegic signaling pathways. Development 131: 1927-1938.

Borzillo, G.V. and Lippa, B. 2005. The Hedgehog signaling pathway as a target for anticancer drug discovery. Curr. Top. Med. Chem. 5: 147-157.

Briscoe, J. and Ericson, J. 2001. Specification of neuronal fates in the ventral neural tube. Curr. Opin. Neurobiol. 11: 43-49.

Briscoe, J., Chen, Y., Jessell, T.M., and Struhl, G. 2001. A hedgehog-insensitive form of patched provides evidence for direct long-range morphogen activity of sonic hedgehog in the neural tube. Mol. Cell 7: 1279-1291.

Britto, J., Tannahill, D., and Keynes, R. 2002. A critical role for sonic hedgehog signaling in the early expansion of the developing brain. Nat. Neurosci. 5: 103-110.

Buglino, J.A. and Resh, M.D. 2008. Hhat is a palmitoylacyl transferase with specificity for N-palmitoylation of sonic hedgehog. J. Biol. Chem. 283: 22076-22088.

Burke, R., Nellen, D., Bellotto, M., Hafen, E., Senti, K.A., Dickson, B.J., and Basler, K. 1999. Dispatched, a novel sterolsensing domain protein dedicated to the release of cholesterol-modified hedgehog from signaling cells. Cell 99: 803815.

Callejo, A., Torroja, C., Quijada, L., and Guerrero, I. 2006. Hedgehog lipid modifications are required for Hedgehog stabilization in the extracellular matrix. Development 133: 471-483.

Casali, A. and Struhl, G. 2004. Reading the Hedgehog morphogen gradient by measuring the ratio of bound to unbound Patched protein. Nature 431: 76-80.

Caspary, T., Garcia-Garcia, M.J., Huangfu, D., Eggenschwiler, J.T., Wyler, M.R., Rakeman, A.S., Alcorn, H.L., and Anderson, K.V. 2002. Mouse Dispatched homolog1 is required for long-range, but not juxtacrine, Hh signaling. Curr. Biol. 12: 1628-1632. 
Caspary, T., Larkins, C.E., and Anderson, K.V. 2007. The graded response to Sonic Hedgehog depends on cilia architecture. Dev. Cell 12: 767-778.

Chamoun, Z., Mann, R.K., Nellen, D., von Kessler, D.P., Bellotto, M., Beachy, P.A., and Basler, K. 2001. Skinny hedgehog, an acyltransferase required for palmitoylation and activity of the hedgehog signal. Science 293: 2080-2084.

Chang, D.T., Lopez, A., von Kessler, D.P., Chiang, C., Simandl, B.K., Zhao, R., Seldin, M.F., Fallon, J.F., and Beachy, P.A. 1994. Products, genetic linkage and limb patterning activity of a murine hedgehog gene. Development 120: 3339-3353.

Chang, B.E., Blader, P., Fischer, N., Ingham, P.W., and Strahle, U. 1997. Axial (HNF3ß) and retinoic acid receptors are regulators of the zebrafish sonic hedgehog promoter. EMBO J. 16: 3955-3964.

Chen, Y. and Struhl, G. 1996. Dual roles for patched in sequestering and transducing Hedgehog. Cell 87: 553-563.

Chen, C.H., von Kessler, D.P., Park, W., Wang, B., Ma, Y., and Beachy, P.A. 1999. Nuclear trafficking of Cubitus interruptus in the transcriptional regulation of Hedgehog target gene expression. Cell 98: 305-316.

Chen, Y., Cardinaux, J.R., Goodman, R.H., and Smolik, S.M. 1999. Mutants of cubitus interruptus that are independent of PKA regulation are independent of hedgehog signaling. Development 126: 3607-3616.

Chen, J.K., Taipale, J., Cooper, M.K., and Beachy, P.A. 2002a. Inhibition of Hedgehog signaling by direct binding of cyclopamine to Smoothened. Genes \& Dev. 16: 2743-2748.

Chen, J.K., Taipale, J., Young, K.E., Maiti, T., and Beachy, P.A. 2002b. Small molecule modulation of Smoothened activity. Proc. Nat1. Acad. Sci. 99: 14071-14076.

Chen, M.H., Li, Y.J., Kawakami, T., Xu, S.M., and Chuang, P.T. 2004. Palmitoylation is required for the production of a soluble multimeric Hedgehog protein complex and longrange signaling in vertebrates. Genes \& Dev. 18: 641-659.

Chen, M.H., Gao, N., Kawakami, T., and Chuang, P.T. 2005. Mice deficient in the fused homolog do not exhibit phenotypes indicative of perturbed hedgehog signaling during embryonic development. Mol. Cell. Biol. 25: 7042-7053.

Chiang, C., Litingtung, Y., Lee, E., Young, K.E., Corden, J.L., Westphal, H., and Beachy, P.A. 1996. Cyclopia and defective axial patterning in mice lacking Sonic hedgehog gene function. Nature 383: 407-413.

Chuang, P.T. and McMahon, A.P. 1999. Vertebrate Hedgehog signalling modulated by induction of a Hedgehog-binding protein. Nature 397: 617-621.

Cobourne, M.T., Hardcastle, Z., and Sharpe, P.T. 2001. Sonic hedgehog regulates epithelial proliferation and cell survival in the developing tooth germ. J. Dent. Res. 80: 1974-1979.

Cobourne, M.T., Miletich, I., and Sharpe, P.T. 2004. Restriction of sonic hedgehog signalling during early tooth development. Development 131: 2875-2885.

Colnot, C., de la Fuente, L., Huang, S., Hu, D., Lu, C., StJacques, B., and Helms, J.A. 2005. Indian hedgehog synchronizes skeletal angiogenesis and perichondrial maturation with cartilage development. Development 132: 1057-1067.

Cooper, M.K., Porter, J.A., Young, K.E., and Beachy, P.A. 1998. Teratogen-mediated inhibition of target tissue response to Shh signaling. Science 280: 1603-1607.

Corbit, K.C., Aanstad, P., Singla, V., Norman, A.R., Stainier, D.Y., and Reiter, J.F. 2005. Vertebrate Smoothened functions at the primary cilium. Nature 437: 1018-1021.

Corcoran, R.B. and Scott, M.P. 2006. Oxysterols stimulate Sonic hedgehog signal transduction and proliferation of medulloblastoma cells. Proc. Natl. Acad. Sci. 103: 8408-8413.

Currie, P.D. and Ingham, P.W. 1996. Induction of a specific muscle cell type by a hedgehog-like protein in zebrafish Nature 382: 452-455.

Dahmane, N. and Ruiz i Altaba, A. 1999. Sonic hedgehog regulates the growth and patterning of the cerebellum. Development 126: 3089-3100.

Dahmane, N., Lee, J., Robins, P., Heller, P., and Ruiz i Altaba, A. 1997. Activation of the transcription factor Glil and the Sonic hedgehog signalling pathway in skin tumours. Nature 389: 876-881.

Dai, P., Shinagawa, T., Nomura, T., Harada, J., Kaul, S.C., Wadhwa, R., Khan, M.M., Akimaru, H., Sasaki, H., Colmenares, C., et al. 2002. Ski is involved in transcriptional regulation by the repressor and full-length forms of Gli3. Genes \& Dev. 16: 2843-2848.

Dawber, R.J., Hebbes, S., Herpers, B., Docquier, F., and van den Heuvel, M. 2005. Differential range and activity of various forms of the Hedgehog protein. BMC Dev. Biol. 5: 21. doi: 10.1186/1471-213X-5-21.

Dessaud, E., Yang, L.L., Hill, K., Cox, B., Ulloa, F., Ribeiro, A., Mynett, A., Novitch, B.G., and Briscoe, J. 2007. Interpretation of the sonic hedgehog morphogen gradient by a temporal adaptation mechanism. Nature 450: 717-720.

Ding, Q., Motoyama, J., Gasca, S., Mo, R., Sasaki, H., Rossant, J., and Hui, C.C. 1998. Diminished Sonic hedgehog signaling and lack of floor plate differentiation in Gli2 mutant mice. Development 125: 2533-2543.

Duman-Scheel, M., Weng, L., Xin, S., and Du, W. 2002. Hedgehog regulates cell growth and proliferation by inducing Cyclin D and Cyclin E. Nature 417: 299-304.

Duprez, D., Fournier-Thibault, C., and Le Douarin, N. 1998. Sonic Hedgehog induces proliferation of committed skeletal muscle cells in the chick limb. Development 125: 495-505.

Dyer, M.A., Farrington, S.M., Mohn, D., Munday, J.R., and Baron, M.H. 2001. Indian hedgehog activates hematopoiesis and vasculogenesis and can respecify prospective neurectodermal cell fate in the mouse embryo. Development 128: $1717-1730$.

Eaton, S. and Kornberg, T.B. 1990. Repression of ci-D in posterior compartments of Drosophila by engrailed. Genes \& Dev. 4: 1068-1077.

Echelard, Y., Epstein, D.J., St-Jacques, B., Shen, L., Mohler, J., McMahon, J.A., and McMahon, A.P. 1993. Sonic hedgehog, a member of a family of putative signaling molecules, is implicated in the regulation of CNS polarity. Cell 75: 14171430.

Ekker, S.C., Ungar, A.R., Greenstein, P., von Kessler, D.P., Porter, J.A., Moon, R.T., and Beachy, P.A. 1995. Patterning activities of vertebrate hedgehog proteins in the developing eye and brain. Curr. Biol. 5: 944-955.

Epstein, D.J., McMahon, A.P., and Joyner, A.L. 1999. Regionalization of Sonic hedgehog transcription along the anteroposterior axis of the mouse central nervous system is regulated by Hnf3-dependent and -independent mechanisms. Development 126: 281-292.

Frank-Kamenetsky, M., Zhang, X.M., Bottega, S., Guicherit, O., Wichterle, H., Dudek, H., Bumcrot, D., Wang, F.Y., Jones, S., Shulok, J., et al. 2002. Small-molecule modulators of Hedgehog signaling: Identification and characterization of Smoothened agonists and antagonists. J. Biol. 1: 10. doi: 10.1186/ 1475-4924-1-10

Fuccillo, M., Joyner, A.L., and Fishell, G. 2006. Morphogen to mitogen: The multiple roles of hedgehog signalling in vertebrate neural development. Nat. Rev. Neurosci. 7: 772-783.

Fuse, N., Maiti, T., Wang, B., Porter, J.A., Hall, T.M., Leahy, D.J., and Beachy, P.A. 1999. Sonic hedgehog protein signals not as a hydrolytic enzyme but as an apparent ligand for 
patched. Proc. Natl. Acad. Sci. 96: 10992-10999.

Gallet, A. and Therond, P.P. 2005. Temporal modulation of the Hedgehog morphogen gradient by a patched-dependent targeting to lysosomal compartment. Dev. Biol. 277: 51-62.

Gallet, A., Ruel, L., Staccini-Lavenant, L., and Therond, P.P. 2006. Cholesterol modification is necessary for controlled planar long-range activity of Hedgehog in Drosophila epithelia. Development 133: 407-418.

Garber, K. 2008. Hedgehog drugs begin to show results. J. Nat1. Cancer Inst. 100: 692-697.

Goddeeris, M.M., Rho, S., Petiet, A., Davenport, C.L., Johnson, G.A., Meyers, E.N., and Klingensmith, J. 2008. Intracardiac septation requires hedgehog-dependent cellular contributions from outside the heart. Development 135: 1887-1895.

Goodrich, L.V., Milenkovic, L., Higgins, K.M., and Scott, M.P. 1997. Altered neural cell fates and medulloblastoma in mouse patched mutants. Science 277: 1109-1113.

Gorlin, R.J. 1987. Nevoid basal-cell carcinoma syndrome. Medicine (Baltimore) 66: 98-113.

Gustafsson, M.K., Pan, H., Pinney, D.F., Liu, Y., Lewandowski, A., Epstein, D.J., and Emerson Jr., C.P. 2002. Myf5 is a direct target of long-range Shh signaling and Gli regulation for muscle specification. Genes \& Dev. 16: 114-126.

Hahn, H., Wicking, C., Zaphiropoulous, P.G., Gailani, M.R., Shanley, S., Chidambaram, A., Vorechovsky, I., Holmberg, E., Unden, A.B., Gillies, S., et al. 1996. Mutations of the human homolog of Drosophila patched in the nevoid basal cell carcinoma syndrome. Cell 85: 841-851.

Hallikas, O., Palin, K., Sinjushina, N., Rautiainen, R., Partanen, J., Ukkonen, E., and Taipale, J. 2006. Genome-wide prediction of mammalian enhancers based on analysis of transcription-factor binding affinity. Cell 124: 47-59.

Hamed, S., LaRue, H., Hovington, H., Girard, J., Jeannotte, L., Latulippe, E., and Fradet, Y. 2004. Accelerated induction of bladder cancer in patched heterozygous mutant mice. Cancer Res. 64: 1938-1942.

Han, C., Belenkaya, T.Y., Khodoun, M., Tauchi, M., Lin, X., and Lin, X. 2004a. Distinct and collaborative roles of Drosophila EXT family proteins in morphogen signalling and gradient formation. Development 131: 1563-1575.

Han, C., Belenkaya, T.Y., Wang, B., and Lin, X. 2004b. Drosophila glypicans control the cell-to-cell movement of Hedgehog by a dynamin-independent process. Development 131: 601-611.

Haraguchi, R., Motoyama, J., Sasaki, H., Satoh, Y., Miyagawa, S., Nakagata, N., Moon, A., and Yamada, G. 2007. Molecular analysis of coordinated bladder and urogenital organ formation by Hedgehog signaling. Development 134: 525-533.

Harfe, B.D., Scherz, P.J., Nissim, S., Tian, H., McMahon, A.P., and Tabin, C.J. 2004. Evidence for an expansion-based temporal Shh gradient in specifying vertebrate digit identities. Cell 118: 517-528.

Hatton, B.A., Knoepfler, P.S., Kenney, A.M., Rowitch, D.H., de Alboran, I.M., Olson, J.M., and Eisenman, R.N. 2006. N-myc is an essential downstream effector of Shh signaling during both normal and neoplastic cerebellar growth. Cancer Res. 66: $8655-8661$.

Haycraft, C.J., Banizs, B., Aydin-Son, Y., Zhang, Q., Michaud, E.J., and Yoder, B.K. 2005. Gli2 and Gli3 localize to cilia and require the intraflagellar transport protein polaris for processing and function. PLoS Genet. 1: e53. doi: 10.1371/ journal.pgen.0010053.

Hebrok, M., Kim, S.K., St Jacques, B., McMahon, A.P., and Melton, D.A. 2000. Regulation of pancreas development by hedgehog signaling. Development 127: 4905-4913.

Hedges, S.B. 2002. The origin and evolution of model organisms.
Nat. Rev. Genet. 3: 838-849.

Hellemans, J., Coucke, P.J., Giedion, A., De Paepe, A., Kramer, P., Beemer, F., and Mortier, G.R. 2003. Homozygous mutations in IHH cause acrocapitofemoral dysplasia, an autosomal recessive disorder with cone-shaped epiphyses in hands and hips. Am. J. Hum. Genet. 72: 1040-1046.

Hill, R.E., Heaney, S.J., and Lettice, L.A. 2003. Sonic hedgehog: Restricted expression and limb dysmorphologies. J. Anat. 202: $13-20$.

Hooper, J.E. 2003. Smoothened translates Hedgehog levels into distinct responses. Development 130: 3951-3963.

Hu, M.C., Mo, R., Bhella, S., Wilson, C.W., Chuang, P.T., Hui, C.C., and Rosenblum, N.D. 2006. GLI3-dependent transcriptional repression of Gli1, Gli2 and kidney patterning genes disrupts renal morphogenesis. Development 133: 569-578.

Huangfu, D. and Anderson, K.V. 2006. Signaling from Smo to Ci/Gli: Conservation and divergence of Hedgehog pathways from Drosophila to vertebrates. Development 133: 3-14.

Huangfu, D., Liu, A., Rakeman, A.S., Murcia, N.S., Niswander, L., and Anderson, K.V. 2003. Hedgehog signalling in the mouse requires intraflagellar transport proteins. Nature $\mathbf{4 2 6}$ : 83-87.

Incardona, J.P., Lee, J.H., Robertson, C.P., Enga, K., Kapur, R.P., and Roelink, H. 2000. Receptor-mediated endocytosis of soluble and membrane-tethered Sonic hedgehog by Patched1. Proc. Natl. Acad. Sci. 97: 12044-12049.

Ingham, P.W. and McMahon, A.P. 2001. Hedgehog signaling in animal development: Paradigms and principles. Genes \& Dev. 15: 3059-3087.

Ingham, P.W., Taylor, A.M., and Nakano, Y. 1991. Role of the Drosophila patched gene in positional signalling. Nature 353: 184-187.

Inoue, Y., Niwa, N., Mito, T., Ohuchi, H., Yoshioka, H., and Noji, S. 2002. Expression patterns of hedgehog, wingless, and decapentaplegic during gut formation of Gryllus bimaculatus (cricket). Mech. Dev. 110: 245-248.

Jacob, J. and Briscoe, J. 2003. Gli proteins and the control of spinal-cord patterning. EMBO Rep. 4: 761-765.

Jacob, L. and Lum, L. 2007a. Hedgehog signaling pathway. Sci. STKE 2007: cm6. doi: $10.1126 /$ stke. $4072007 \mathrm{~cm} 6$.

Jacob, L. and Lum, L. 2007b. Hedgehog signaling pathway in Drosophila. Sci. STKE 2007: cm7. doi: 10.1126/stke. $4072007 \mathrm{~cm} 7$.

Jaillon, O., Aury, J.M., Brunet, F., Petit, J.L., Stange-Thomann, N., Mauceli, E., Bouneau, L., Fischer, C., Ozouf-Costaz, C., Bernot, A., et al. 2004. Genome duplication in the teleost fish Tetraodon nigroviridis reveals the early vertebrate proto-karyotype. Nature 431: 946-957.

Jensen, A.M. and Wallace, V.A. 1997. Expression of Sonic hedgehog and its putative role as a precursor cell mitogen in the developing mouse retina. Development 124: 363-371.

Jeong, Y. and Epstein, D.J. 2003. Distinct regulators of Shh transcription in the floor plate and notochord indicate separate origins for these tissues in the mouse node. Development 130: 3891-3902.

Jeong, J. and McMahon, A.P. 2005. Growth and pattern of the mammalian neural tube are governed by partially overlapping feedback activities of the hedgehog antagonists patched 1 and Hhip1. Development 132: 143-154.

Jeong, J., Mao, J., Tenzen, T., Kottmann, A.H., and McMahon, A.P. 2004. Hedgehog signaling in the neural crest cells regulates the patterning and growth of facial primordia. Genes \& Dev. 18: 937-951.

Jeong, Y., El-Jaick, K., Roessler, E., Muenke, M., and Epstein, D.J. 2006. A functional screen for sonic hedgehog regulatory elements across a $1 \mathrm{Mb}$ interval identifies long-range ventral 
forebrain enhancers. Development 133: 761-772.

Jessell, T.M. 2000. Neuronal specification in the spinal cord: Inductive signals and transcriptional codes. Nat. Rev. Genet. 1: 20-29.

Jia, J., Amanai, K., Wang, G., Tang, J., Wang, B., and Jiang, J. 2002. Shaggy/GSK3 antagonizes Hedgehog signalling by regulating Cubitus interruptus. Nature 416: 548-552.

Jia, J., Tong, C., and Jiang, J. 2003. Smoothened transduces Hedgehog signal by physically interacting with Costal2/ Fused complex through its C-terminal tail. Genes \& Dev. 17: 2709-2720.

Jia, J., Tong, C., Wang, B., Luo, L., and Jiang, J. 2004. Hedgehog signalling activity of Smoothened requires phosphorylation by protein kinase A and casein kinase I. Nature 432: 10451050.

Jia, J., Zhang, L., Zhang, Q., Tong, C., Wang, B., Hou, F., Amanai, K., and Jiang, J. 2005. Phosphorylation by double-time/ $\mathrm{CKI} \varepsilon$ and $\mathrm{CKI} \alpha$ targets cubitus interruptus for $\mathrm{Slimb} / \beta$ TRCP-mediated proteolytic processing. Dev. Cell 9: 819-830.

Jiang, J. and Struhl, G. 1998. Regulation of the Hedgehog and Wingless signalling pathways by the F-box/WD40-repeat protein Slimb. Nature 391: 493-496.

Johnson, R.L., Laufer, E., Riddle, R.D., and Tabin, C. 1994. Ectopic expression of Sonic hedgehog alters dorsal-ventral patterning of somites. Cell 79: 1165-1173.

Johnson, R.L., Rothman, A.L., Xie, J., Goodrich, L.V., Bare, J.W., Bonifas, J.M., Quinn, A.G., Myers, R.M., Cox, D.R., Epstein Jr., E.H., et al. 1996. Human homolog of patched, a candidate gene for the basal cell nevus syndrome. Science 272: 16681671.

Kappler, R., Bauer, R., Calzada-Wack, J., Rosemann, M., Hemmerlein, B., and Hahn, H. 2004. Profiling the molecular difference between Patched- and p53-dependent rhabdomyosarcoma. Oncogene 23: 8785-8795.

Karhadkar, S.S., Bova, G.S., Abdallah, N., Dhara, S., Gardner, D., Maitra, A., Isaacs, J.T., Berman, D.M., and Beachy, P.A. 2004. Hedgehog signalling in prostate regeneration, neoplasia and metastasis. Nature 431: 707-712.

Katanaev, V.L., Solis, G.P., Hausmann, G., Buestorf, S., Katanayeva, N., Schrock, Y., Stuermer, C.A., and Basler, K. 2008. Reggie-1/flotillin-2 promotes secretion of the long-range signalling forms of Wingless and Hedgehog in Drosophila. EMBO J. 27: 509-521.

Keeler, R.F. and Binns, W. 1966. Teratogenic compounds of Veratrum californicum (Durand). I. Preparation and characterization of fractions and alkaloids for biologic testing. Can. J. Biochem. 44: 819-828.

Kelley, R.L., Roessler, E., Hennekam, R.C., Feldman, G.L., Kosaki, K., Jones, M.C., Palumbos, J.C., and Muenke, M. 1996. Holoprosencephaly in RSH/Smith-Lemli-Opitz syndrome: Does abnormal cholesterol metabolism affect the function of Sonic Hedgehog? Am. J. Med. Genet. 66: 478-484.

Kenney, A.M., Cole, M.D., and Rowitch, D.H. 2003. Nmyc upregulation by sonic hedgehog signaling promotes proliferation in developing cerebellar granule neuron precursors. Development 130: 15-28.

Kent, D., Bush, E.W., and Hooper, J.E. 2006. Roadkill attenuates Hedgehog responses through degradation of Cubitus interruptus. Development 133: 2001-2010.

Kimura, H., Ng, J.M., and Curran, T. 2008. Transient inhibition of the Hedgehog pathway in young mice causes permanent defects in bone structure. Cancer Cell 13: 249-260.

Kinto, N., Iwamoto, M., Enomoto-Iwamoto, M., Noji, S., Ohuchi, H., Yoshioka, H., Kataoka, H., Wada, Y., Yuhao, G., Takahashi, H.E., et al. 1997. Fibroblasts expressing Sonic hedgehog induce osteoblast differentiation and ectopic bone formation. FEBS Lett. 404: 319-323.

Kinzler, K.W. and Vogelstein, B. 1990. The GLI gene encodes a nuclear protein which binds specific sequences in the human genome. Mol. Cell. Biol. 10: 634-642.

Kinzler, K.W., Bigner, S.H., Bigner, D.D., Trent, J.M., Law, M.L., O'Brien, S.J., Wong, A.J., and Vogelstein, B. 1987. Identification of an amplified, highly expressed gene in a human glioma. Science 236: 70-73

Knoepfler, P.S., Cheng, P.F., and Eisenman, R.N. 2002. N-myc is essential during neurogenesis for the rapid expansion of progenitor cell populations and the inhibition of neuronal differentiation. Genes \& Dev. 16: 2699-2712.

Koziel, L., Kunath, M., Kelly, O.G., and Vortkamp, A. 2004. Ext1-dependent heparan sulfate regulates the range of Ihh signaling during endochondral ossification. Dev. Cell 6: 801813.

Krauss, S., Concordet, J.P., and Ingham, P.W. 1993. A functionally conserved homolog of the Drosophila segment polarity gene hh is expressed in tissues with polarizing activity in zebrafish embryos. Cell 75: 1431-1444.

Kubo, M., Nakamura, M., Tasaki, A., Yamanaka, N., Nakashima, H., Nomura, M., Kuroki, S., and Katano, M. 2004. Hedgehog signaling pathway is a new therapeutic target for patients with breast cancer. Cancer Res. 64: 6071-6074.

Kuwabara, P.E., Lee, M.H., Schedl, T., and Jefferis, G.S. 2000. A C. elegans patched gene, ptc-1, functions in germ-line cytokinesis. Genes \& Dev. 14: 1933-1944.

Kyttala, M., Tallila, J., Salonen, R., Kopra, O., Kohlschmidt, N., Paavola-Sakki, P., Peltonen, L., and Kestila, M. 2006. MKS1, encoding a component of the flagellar apparatus basal body proteome, is mutated in Meckel syndrome. Nat. Genet. 38: $155-157$.

Laufer, E., Nelson, C.E., Johnson, R.L., Morgan, B.A., and Tabin, C. 1994. Sonic hedgehog and Fgf-4 act through a signaling cascade and feedback loop to integrate growth and patterning of the developing limb bud. Cell 79: 993-1003.

Lee, J.D. and Treisman, J.E. 2001. Sightless has homology to transmembrane acyltransferases and is required to generate active Hedgehog protein. Curr. Biol. 11: 1147-1152.

Lee, J.J., von Kessler, D.P., Parks, S., and Beachy, P.A. 1992. Secretion and localized transcription suggest a role in positional signaling for products of the segmentation gene hedgehog. Cell 71: 33-50.

Lee, J.J., Ekker, S.C., von Kessler, D.P., Porter, J.A., Sun, B.I., and Beachy, P.A. 1994. Autoproteolysis in hedgehog protein biogenesis. Science 266: 1528-1537.

Lee, J.D., Kraus, P., Gaiano, N., Nery, S., Kohtz, J., Fishell, G., Loomis, C.A., and Treisman, J.E. 2001. An acylatable residue of Hedgehog is differentially required in Drosophila and mouse limb development. Dev. Biol. 233: 122-136.

Lee, Y., Miller, H.L., Russell, H.R., Boyd, K., Curran, T., and McKinnon, P.J. 2006. Patched2 modulates tumorigenesis in patched1 heterozygous mice. Cancer Res. 66: 6964-6971.

Lefers, M.A., Wang, Q.T., and Holmgren, R.A. 2001. Genetic dissection of the Drosophila Cubitus interruptus signaling complex. Dev. Biol. 236: 411-420.

Lettice, L.A., Heaney, S.J., Purdie, L.A., Li, L., de Beer, P., Oostra, B.A., Goode, D., Elgar, G., Hill, R.E., and de Graaff, E. 2003. A long-range Shh enhancer regulates expression in the developing limb and fin and is associated with preaxial polydactyly. Hum. Mol. Genet. 12: 1725-1735.

Lettre, G., Jackson, A.U., Gieger, C., Schumacher, F.R., Berndt, S.I., Sanna, S., Eyheramendy, S., Voight, B.F., Butler, J.L., Guiducci, C., et al. 2008. Identification of ten loci associated with height highlights new biological pathways in human 
growth. Nat. Genet. 40: 584-591.

Lewis, P.M., Dunn, M.P., McMahon, J.A., Logan, M., Martin, J.F., St-Jacques, B., and McMahon, A.P. 2001. Cholesterol modification of sonic hedgehog is required for long-range signaling activity and effective modulation of signaling by Ptc1. Cell 105: 599-612.

Li, Y., Zhang, H., Litingtung, Y., and Chiang, C. 2006. Cholesterol modification restricts the spread of Shh gradient in the limb bud. Proc. Natl. Acad. Sci. 103: 6548-6553.

Lin, X., Wei, G., Shi, Z., Dryer, L., Esko, J.D., Wells, D.E., and Matzuk, M.M. 2000. Disruption of gastrulation and heparan sulfate biosynthesis in EXT1-deficient mice. Dev. Biol. 224: 299-311.

Litingtung, Y., Lei, L., Westphal, H., and Chiang, C. 1998. Sonic hedgehog is essential to foregut development. Nat. Genet. 20: $58-61$.

Litingtung, Y., Dahn, R.D., Li, Y., Fallon, J.F., and Chiang, C. 2002. Shh and Gli3 are dispensable for limb skeleton formation but regulate digit number and identity. Nature 418: 979-983.

Liu, A., Joyner, A.L., and Turnbull, D.H. 1998. Alteration of limb and brain patterning in early mouse embryos by ultrasound-guided injection of Shh-expressing cells. Mech. Dev. 75: 107-115.

Loytynoja, A. and Goldman, N. 2005. An algorithm for progressive multiple alignment of sequences with insertions. Proc. Natl. Acad. Sci. 102: 10557-10562.

Lum, L. and Beachy, P.A. 2004. The Hedgehog response network: Sensors, switches, and routers. Science 304: 1755-1759.

Lum, L., Yao, S., Mozer, B., Rovescalli, A., Von Kessler, D., Nirenberg, M., and Beachy, P.A. 2003a. Identification of Hedgehog pathway components by RNAi in Drosophila cultured cells. Science 299: 2039-2045.

Lum, L., Zhang, C., Oh, S., Mann, R.K., von Kessler, D.P., Taipale, J., Weis-Garcia, F., Gong, R., Wang, B., and Beachy, P.A. 2003b. Hedgehog signal transduction via Smoothened association with a cytoplasmic complex scaffolded by the atypical kinesin, Costal-2. Mol. Cell 12: 1261-1274.

Ma, Y., Erkner, A., Gong, R., Yao, S., Taipale, J., Basler, K., and Beachy, P.A. 2002. Hedgehog-mediated patterning of the mammalian embryo requires transporter-like function of dispatched. Cell 111: 63-75.

Madison, B.B., Braunstein, K., Kuizon, E., Portman, K., Qiao, X.T., and Gumucio, D.L. 2005. Epithelial hedgehog signals pattern the intestinal crypt-villus axis. Development 132: 279-289.

Maeda, Y., Nakamura, E., Nguyen, M.T., Suva, L.J., Swain, F.L., Razzaque, M.S., Mackem, S., and Lanske, B. 2007. Indian Hedgehog produced by postnatal chondrocytes is essential for maintaining a growth plate and trabecular bone. Proc. Natl. Acad. Sci. 104: 6382-6387.

Mak, K.K., Bi, Y., Wan, C., Chuang, P.T., Clemens, T., Young, M., and Yang, Y. 2008. Hedgehog signaling in mature osteoblasts regulates bone formation and resorption by controlling PTHrP and RANKL expression. Dev. Cell 14: 674-688.

Mann, R.K. and Beachy, P.A. 2004. Novel lipid modifications of secreted protein signals. Annu. Rev. Biochem. 73: 891-923.

Mao, J., Maye, P., Kogerman, P., Tejedor, F.J., Toftgard, R., Xie, W., Wu, G., and Wu, D. 2002. Regulation of Glil transcriptional activity in the nucleus by Dyrk1. J. Biol. Chem. 277: 35156-35161.

Marigo, V., Roberts, D.J., Lee, S.M., Tsukurov, O., Levi, T., Gastier, J.M., Epstein, D.J., Gilbert, D.J., Copeland, N.G., Seidman, C.E., et al. 1995. Cloning, expression, and chromosomal location of SHH and IHH: Two human homologues of the Drosophila segment polarity gene hedgehog. Genomics 28: 44-51.

Marti, E. and Bovolenta, P. 2002. Sonic hedgehog in CNS development: One signal, multiple outputs. Trends Neurosci. 25: 89-96.

Marti, E., Takada, R., Bumcrot, D.A., Sasaki, H., and McMahon, A.P. 1995. Distribution of Sonic hedgehog peptides in the developing chick and mouse embryo. Development 121: 2537-2547.

Matise, M.P., Epstein, D.J., Park, H.L., Platt, K.A., and Joyner, A.L. 1998. Gli2 is required for induction of floor plate and adjacent cells, but not most ventral neurons in the mouse central nervous system. Development 125: 2759-2770.

May, S.R., Ashique, A.M., Karlen, M., Wang, B., Shen, Y., Zarbalis, K., Reiter, J., Ericson, J., and Peterson, A.S. 2005. Loss of the retrograde motor for IFT disrupts localization of Smo to cilia and prevents the expression of both activator and repressor functions of Gli. Dev. Biol. 287: 378-389.

McMahon, A.P., Ingham, P.W., and Tabin, C.J. 2003. Developmental roles and clinical significance of hedgehog signaling. Curr. Top. Dev. Biol. 53: 1-114.

Merchant, M., Evangelista, M., Luoh, S.M., Frantz, G.D., Chalasani, S., Carano, R.A., van Hoy, M., Ramirez, J., Ogasawara, A.K., McFarland, L.M., et al. 2005. Loss of the serine/ threonine kinase fused results in postnatal growth defects and lethality due to progressive hydrocephalus. Mol. Cell. Biol. 25: 7054-7068.

Methot, N. and Basler, K. 1999. Hedgehog controls limb development by regulating the activities of distinct transcriptional activator and repressor forms of Cubitus interruptus. Cell 96: 819-831.

Methot, N. and Basler, K. 2000. Suppressor of fused opposes hedgehog signal transduction by impeding nuclear accumulation of the activator form of Cubitus interruptus. Development 127: 4001-4010.

Meyer, N.P. and Roelink, H. 2003. The amino-terminal region of Gli3 antagonizes the Shh response and acts in dorsoventral fate specification in the developing spinal cord. Dev. Biol. 257: 343-355.

Miura, H., Kusakabe, Y., Sugiyama, C., Kawamatsu, M., Ninomiya, Y., Motoyama, J., and Hino, A. 2001. Shh and Ptc are associated with taste bud maintenance in the adult mouse. Mech. Dev. 106: 143-145.

Mo, R., Freer, A.M., Zinyk, D.L., Crackower, M.A., Michaud, J., Heng, H.H., Chik, K.W., Shi, X.M., Tsui, L.C., Cheng, S.H., et al. 1997. Specific and redundant functions of Gli2 and Gli3 zinc finger genes in skeletal patterning and development. Development 124: 113-123.

Mohler, J. and Vani, K. 1992. Molecular organization and embryonic expression of the hedgehog gene involved in cell-cell communication in segmental patterning of Drosophila. Development 115: 957-971.

Muenke, M. and Beachy, P.A. 2000. Genetics of ventral forebrain development and holoprosencephaly. Curr. Opin. Genet. Dev. 10: 262-269.

Murone, M., Luoh, S.M., Stone, D., Li, W., Gurney, A., Armanini, M., Grey, C., Rosenthal, A., and de Sauvage, F.J. 2000. Gli regulation by the opposing activities of fused and suppressor of fused. Nat. Cell Biol. 2: 310-312.

Nagase, T., Nagase, M., Machida, M., and Fujita, T. 2008. Hedgehog signalling in vascular development. Angiogenesis 11: 71-77.

Nagata, K., Puls, A., Futter, C., Aspenstrom, P., Schaefer, E., Nakata, T., Hirokawa, N., and Hall, A. 1998. The MAP kinase kinase kinase MLK2 co-localizes with activated JNK along microtubules and associates with kinesin superfamily 
motor KIF3. EMBO J. 17: 149-158.

Nakato, H., Futch, T.A., and Selleck, S.B. 1995. The division abnormally delayed (dally) gene: A putative integral membrane proteoglycan required for cell division patterning during postembryonic development of the nervous system in Drosophila. Development 121: 3687-3702.

Nieuwenhuis, E., Motoyama, J., Barnfield, P.C., Yoshikawa, Y., Zhang, X., Mo, R., Crackower, M.A., and Hui, C.C. 2006. Mice with a targeted mutation of patched2 are viable but develop alopecia and epidermal hyperplasia. Mol. Cell. Biol. 26: 6609-6622.

Nishimaki, H., Kasai, K., Kozaki, K., Takeo, T., Ikeda, H., Saga, S., Nitta, M., and Itoh, G. 2004. A role of activated Sonic hedgehog signaling for the cellular proliferation of oral squamous cell carcinoma cell line. Biochem. Biophys. Res. Commun. 314: 313-320.

Nusslein-Volhard, C. and Wieschaus, E. 1980. Mutations affecting segment number and polarity in Drosophila. Nature 287: $795-801$.

Nybakken, K., Vokes, S.A., Lin, T.Y., McMahon, A.P., and Perrimon, N. 2005. A genome-wide RNA interference screen in Drosophila melanogaster cells for new components of the Hh signaling pathway. Nat. Genet. 37: 1323-1332.

Ogden, S.K., Ascano Jr., M., Stegman, M.A., Suber, L.M., Hooper, J.E., and Robbins, D.J. 2003. Identification of a functional interaction between the transmembrane protein Smoothened and the kinesin-related protein Costal2. Curr. Biol. 13: 1998-2003.

Ohba, S., Kawaguchi, H., Kugimiya, F., Ogasawara, T., Kawamura, N., Saito, T., Ikeda, T., Fujii, K., Miyajima, T., Kuramochi, A., et al. 2008. Patched1 haploinsufficiency increases adult bone mass and modulates Gli3 repressor activity. Dev. Cell 14: 689-699.

Ohlmeyer, J.T. and Kalderon, D. 1998. Hedgehog stimulates maturation of Cubitus interruptus into a labile transcriptional activator. Nature 396: 749-753.

Oliver, T.G., Grasfeder, L.L., Carroll, A.L., Kaiser, C., Gillingham, C.L., Lin, S.M., Wickramasinghe, R., Scott, M.P., and Wechsler-Reya, R.J. 2003. Transcriptional profiling of the Sonic hedgehog response: A critical role for N-myc in proliferation of neuronal precursors. Proc. Natl. Acad. Sci. 100: 7331-7336.

Pagan-Westphal, S.M. and Tabin, C.J. 1998. The transfer of leftright positional information during chick embryogenesis. Cell 93: 25-35.

Pan, J., Wang, Q., and Snell, W.J. 2005. Cilium-generated signaling and cilia-related disorders. Lab. Invest. 85: 452-463.

Pan, Y., Bai, C.B., Joyner, A.L., and Wang, B. 2006. Sonic hedgehog signaling regulates Gli2 transcriptional activity by suppressing its processing and degradation. Mol. Cell. Biol. 26: 3365-3377.

Panakova, D., Sprong, H., Marois, E., Thiele, C., and Eaton, S. 2005. Lipoprotein particles are required for Hedgehog and Wingless signalling. Nature 435: 58-65.

Pangas, S.A. 2007. Growth factors in ovarian development. Semin. Reprod. Med. 25: 225-234.

Park, H.L., Bai, C., Platt, K.A., Matise, M.P., Beeghly, A., Hui, C.C., Nakashima, M., and Joyner, A.L. 2000. Mouse Gli1 mutants are viable but have defects in SHH signaling in combination with a Gli2 mutation. Development 127: 15931605.

Park, T.J., Haigo, S.L., and Wallingford, J.B. 2006. Ciliogenesis defects in embryos lacking inturned or fuzzy function are associated with failure of planar cell polarity and Hedgehog signaling. Nat. Genet. 38: 303-311.

Patten, I. and Placzek, M. 2000. The role of Sonic hedgehog in neural tube patterning. Cell. Mol. Life Sci. 57: 1695-1708.

Pepicelli, C.V., Lewis, P.M., and McMahon, A.P. 1998. Sonic hedgehog regulates branching morphogenesis in the mammalian lung. Curr. Biol. 8: 1083-1086.

Pepinsky, R.B., Zeng, C., Wen, D., Rayhorn, P., Baker, D.P. Williams, K.P., Bixler, S.A., Ambrose, C.M., Garber, E.A., Miatkowski, K., et al. 1998. Identification of a palmitic acidmodified form of human Sonic hedgehog. J. Biol. Chem. 273: 14037-14045.

Pham, A., Therond, P., Alves, G., Tournier, F.B., Busson, D., Lamour-Isnard, C., Bouchon, B.L., Preat, T., and Tricoire, H. 1995. The Suppressor of fused gene encodes a novel PEST protein involved in Drosophila segment polarity establish ment. Genetics 140: 587-598.

Pierani, A., Brenner-Morton, S., Chiang, C., and Jessell, T.M. 1999. A sonic hedgehog-independent, retinoid-activated pathway of neurogenesis in the ventral spinal cord. Cell 97: 903-915.

Pires-daSilva, A. and Sommer, R.J. 2003. The evolution of signalling pathways in animal development. Nat. Rev. Genet. 4: $39-49$.

Pola, R., Ling, L.E., Silver, M., Corbley, M.J., Kearney, M., Blake Pepinsky, R., Shapiro, R., Taylor, F.R., Baker, D.P., Asahara, T., et al. 2001. The morphogen Sonic hedgehog is an indirect angiogenic agent upregulating two families of angiogenic growth factors. Nat. Med. 7: 706-711.

Porter, J.A., Young, K.E., and Beachy, P.A. 1996. Cholesterol modification of hedgehog signaling proteins in animal development. Science 274: 255-259.

Price, M.A. and Kalderon, D. 1999. Proteolysis of cubitus interruptus in Drosophila requires phosphorylation by protein kinase A. Development 126: 4331-4339.

Price, M.A. and Kalderon, D. 2002. Proteolysis of the Hedgehog signaling effector Cubitus interruptus requires phosphorylation by Glycogen Synthase Kinase 3 and Casein Kinase 1. Cell 108: 823-835.

Razzaque, M.S., Soegiarto, D.W., Chang, D., Long, F., and Lanske, B. 2005. Conditional deletion of Indian hedgehog from collagen type $2 \alpha 1$-expressing cells results in abnormal endochondral bone formation. J. Pathol. 207: 453-461.

Riccomagno, M.M., Martinu, L., Mulheisen, M., Wu, D.K., and Epstein, D.J. 2002. Specification of the mammalian cochlea is dependent on Sonic hedgehog. Genes \& Dev. 16: 23652378.

Riddle, R.D., Johnson, R.L., Laufer, E., and Tabin, C. 1993. Sonic hedgehog mediates the polarizing activity of the ZPA. Cell 75: 1401-1416.

Riobo, N.A., Haines, G.M., and Emerson Jr., C.P. 2006a. Protein kinase $\mathrm{C}-\delta$ and mitogen-activated protein/extracellular signal-regulated kinase-1 control GLI activation in hedgehog signaling. Cancer Res. 66: 839-845.

Riobo, N.A., Lu, K., Ai, X., Haines, G.M., and Emerson Jr., C.P. 2006b. Phosphoinositide 3-kinase and Akt are essential for Sonic Hedgehog signaling. Proc. Natl. Acad. Sci. 103: 45054510.

Robbins, D.J., Nybakken, K.E., Kobayashi, R., Sisson, J.C., Bishop, J.M., and Therond, P.P. 1997. Hedgehog elicits signal transduction by means of a large complex containing the kinesin-related protein costal2. Cell 90: 225-234.

Roelink, H., Augsburger, A., Heemskerk, J., Korzh, V., Norlin, S., Ruiz i Altaba, A., Tanabe, Y., Placzek, M., Edlund, T., Jessell, T.M., et al. 1994. Floor plate and motor neuron induction by vhh-1, a vertebrate homolog of hedgehog expressed by the notochord. Cell 76: 761-775.

Roelink, H., Porter, J.A., Chiang, C., Tanabe, Y., Chang, D.T., Beachy, P.A., and Jessell, T.M. 1995. Floor plate and motor 
neuron induction by different concentrations of the aminoterminal cleavage product of sonic hedgehog autoproteolysis. Cell 81: 445-455.

Rohatgi, R., Milenkovic, L., and Scott, M.P. 2007. Patched1 regulates hedgehog signaling at the primary cilium. Science 317: 372-376.

Rowitch, D.H., St.-Jacques, B., Lee, S.M., Flax, J.D., Snyder, E.Y., and McMahon, A.P. 1999. Sonic hedgehog regulates proliferation and inhibits differentiation of CNS precursor cells. J. Neurosci. 19: 8954-8965.

Ruel, L., Rodriguez, R., Gallet, A., Lavenant-Staccini, L., and Therond, P.P. 2003. Stability and association of Smoothened, Costal2 and Fused with Cubitus interruptus are regulated by Hedgehog. Nat. Cell Biol. 5: 907-913.

Ruiz i Altaba, A., Mas, C., and Stecca, B. 2007. The Gli code: An information nexus regulating cell fate, stemness and cancer. Trends Cell Biol. 17: 438-447.

Sagai, T., Masuya, H., Tamura, M., Shimizu, K., Yada, Y., Wakana, S., Gondo, Y., Noda, T., and Shiroishi, T. 2004. Phylogenetic conservation of a limb-specific, cis-acting regulator of Sonic hedgehog (Shh). Mamm. Genome 15: 23-34.

Sagai, T., Hosoya, M., Mizushina, Y., Tamura, M., and Shiroishi, T. 2005. Elimination of a long-range cis-regulatory module causes complete loss of limb-specific Shh expression and truncation of the mouse limb. Development 132: 797-803.

Sampath, K., Cheng, A.M., Frisch, A., and Wright, C.V. 1997. Functional differences among Xenopus nodal-related genes in left-right axis determination. Development 124: 3293-3302.

Sanchez, P., Hernandez, A.M., Stecca, B., Kahler, A.J., DeGueme, A.M., Barrett, A., Beyna, M., Datta, M.W., Datta, S., and Ruiz i Altaba, A. 2004. Inhibition of prostate cancer proliferation by interference with SONIC HEDGEHOGGLI1 signaling. Proc. Natl. Acad. Sci. 101: 12561-12566.

Schilling, T.F., Concordet, J.P., and Ingham, P.W. 1999. Regulation of left-right asymmetries in the zebrafish by Shh and BMP4. Dev. Biol. 210: 277-287.

Schimmang, T., Lemaistre, M., Vortkamp, A., and Ruther, U. 1992. Expression of the zinc finger gene Gli3 is affected in the morphogenetic mouse mutant extra-toes $(\mathrm{Xt})$. Development 116: 799-804.

Sharpe, J., Lettice, L., Hecksher-Sorensen, J., Fox, M., Hill, R., and Krumlauf, R. 1999. Identification of sonic hedgehog as a candidate gene responsible for the polydactylous mouse mutant Sasquatch. Curr. Biol. 9: 97-100.

Shimeld, S.M. 1999. The evolution of the hedgehog gene family in chordates: Insights from amphioxus hedgehog. Dev. Genes Evol. 209: 40-47.

Sigulinsky, C.L., Green, E.S., Clark, A.M., and Levine, E.M. 2008. Vsx2/Chx10 ensures the correct timing and magnitude of Hedgehog signaling in the mouse retina. Dev. Biol. 317: 560-575.

Sillitoe, R.V. and Joyner, A.L. 2007. Morphology, molecular codes, and circuitry produce the three-dimensional complexity of the cerebellum. Annu. Rev. Cell Dev. Biol. 23: 549577.

St-Jacques, B., Dassule, H.R., Karavanova, I., Botchkarev, V.A., Li, J., Danielian, P.S., McMahon, J.A., Lewis, P.M., Paus, R., and McMahon, A.P. 1998. Sonic hedgehog signaling is essential for hair development. Curr. Biol. 8: 1058-1068.

St-Jacques, B., Hammerschmidt, M., and McMahon, A.P. 1999. Indian hedgehog signaling regulates proliferation and differentiation of chondrocytes and is essential for bone formation. Genes \& Dev. 13: 2072-2086.

Stone, D.M., Hynes, M., Armanini, M., Swanson, T.A., Gu, Q., Johnson, R.L., Scott, M.P., Pennica, D., Goddard, A., Phil- lips, H., et al. 1996. The tumour-suppressor gene patched encodes a candidate receptor for Sonic hedgehog. Nature 384: 129-134.

Svard, J., Heby-Henricson, K., Persson-Lek, M., Rozell, B., Lauth, M., Bergstrom, A., Ericson, J., Toftgard, R., and Teglund, S. 2006. Genetic elimination of Suppressor of fused reveals an essential repressor function in the mammalian Hedgehog signaling pathway. Dev. Cell 10: 187-197.

Tabata, T. and Kornberg, T.B. 1994. Hedgehog is a signaling protein with a key role in patterning Drosophila imaginal discs. Cell 76: 89-102.

Tabata, T., Eaton, S., and Kornberg, T.B. 1992. The Drosophila hedgehog gene is expressed specifically in posterior compartment cells and is a target of engrailed regulation. Genes \& Dev. 6: 2635-2645.

Taipale, J. and Beachy, P.A. 2001. The Hedgehog and Wnt signalling pathways in cancer. Nature 411: 349-354.

Taipale, J., Chen, J.K., Cooper, M.K., Wang, B., Mann, R.K., Milenkovic, L., Scott, M.P., and Beachy, P.A. 2000. Effects of oncogenic mutations in Smoothened and Patched can be reversed by cyclopamine. Nature 406: 1005-1009.

Taipale, J., Cooper, M.K., Maiti, T., and Beachy, P.A. 2002 Patched acts catalytically to suppress the activity of Smoothened. Nature 418: 892-897.

Tashiro, S., Michiue, T., Higashijima, S., Zenno, S., Ishimaru, S., Takahashi, F., Orihara, M., Kojima, T., and Saigo, K. 1993. Structure and expression of hedgehog, a Drosophila segment-polarity gene required for cell-cell communication. Gene 124: 183-189.

Teleman, A.A., Strigini, M., and Cohen, S.M. 2001. Shaping morphogen gradients. Cell 105: 559-562.

Tenzen, T., Allen, B.L., Cole, F., Kang, J.S., Krauss, R.S., and McMahon, A.P. 2006. The cell surface membrane proteins Cdo and Boc are components and targets of the Hedgehog signaling pathway and feedback network in mice. Dev. Cell 10: $647-656$.

Thayer, S.P., di Magliano, M.P., Heiser, P.W., Nielsen, C.M., Roberts, D.J., Lauwers, G.Y., Qi, Y.P., Gysin, S., Fernandezdel Castillo, C., Yajnik, V., et al. 2003. Hedgehog is an early and late mediator of pancreatic cancer tumorigenesis. $\mathrm{Na}$ ture 425: 851-856.

Theiler, K. 1989. The house mouse: Atlas of embryonic development. Springer-Verlag, New York.

Therond, P.P., Knight, J.D., Kornberg, T.B., and Bishop, J.M. 1996. Phosphorylation of the fused protein kinase in response to signaling from hedgehog. Proc. Natl. Acad. Sci. 93: 4224-4228.

van den Brink, G.R. 2007. Hedgehog signaling in development and homeostasis of the gastrointestinal tract. Physiol. Rev. 87: 1343-1375.

van den Heuvel, M. and Ingham, P.W. 1996. smoothened encodes a receptor-like serpentine protein required for hedgehog signalling. Nature 382: 547-551.

Varjosalo, M. and Taipale, J. 2007. Hedgehog signaling. J. Cell Sci. 120: 3-6.

Varjosalo, M., Li, S.P., and Taipale, J. 2006. Divergence of hedgehog signal transduction mechanism between Drosophila and mammals. Dev. Cell 10: 177-186.

Varjosalo, M., Bjorklund, M., Cheng, F., Syvanen, H., Kivioja, T., Kilpinen, S., Sun, Z., Kallioniemi, O., Stunnenberg, H.G., He, W.W., et al. 2008. Application of active and kinase-deficient kinome collection for identification of kinases regulating hedgehog signaling. Cell 133: 537-548.

Vierkotten, J., Dildrop, R., Peters, T., Wang, B., and Ruther, U. 2007. Ftm is a novel basal body protein of cilia involved in Shh signalling. Development 134: 2569-2577. 
Vokes, S.A., Ji, H., McCuine, S., Tenzen, T., Giles, S., Zhong, S., Longabaugh, W.J., Davidson, E.H., Wong, W.H., and McMahon, A.P. 2007. Genomic characterization of Gli-activator targets in sonic hedgehog-mediated neural patterning. Development 134: 1977-1989.

Vortkamp, A., Gessler, M., and Grzeschik, K.H. 1991. GLI3 zinc-finger gene interrupted by translocations in Greig syndrome families. Nature 352: 539-540.

Vortkamp, A., Lee, K., Lanske, B., Segre, G.V., Kronenberg, H.M., and Tabin, C.J. 1996. Regulation of rate of cartilage differentiation by Indian hedgehog and PTH-related protein. Science 273: 613-622.

Wada, H. and Makabe, K. 2006. Genome duplications of early vertebrates as a possible chronicle of the evolutionary history of the neural crest. Int. I. Biol. Sci. 2: 133-141.

Wallace, V.A. and Raff, M.C. 1999. A role for Sonic hedgehog in axon-to-astrocyte signalling in the rodent optic nerve. Development 126: 2901-2909.

Wang, B. and Li, Y. 2006. Evidence for the direct involvement of $\{\beta\}$ TrCP in Gli3 protein processing. Proc. Natl. Acad. Sci. 103: 33-38.

Wang, G., Wang, B., and Jiang, J. 1999. Protein kinase A antagonizes Hedgehog signaling by regulating both the activator and repressor forms of Cubitus interruptus. Genes \& Dev. 13: $2828-2837$.

Wang, B., Fallon, J.F., and Beachy, P.A. 2000. Hedgehog-regulated processing of Gli3 produces an anterior/posterior repressor gradient in the developing vertebrate limb. Cell 100: 423-434.

Wang, G., Amanai, K., Wang, B., and Jiang, J. 2000. Interactions with Costal2 and suppressor of fused regulate nuclear translocation and activity of cubitus interruptus. Genes \& Dev. 14: 2893-2905.

Watanabe, Y. and Nakamura, H. 2000. Control of chick tectum territory along dorsoventral axis by Sonic hedgehog. Development 127: 1131-1140.

Watkins, D.N. and Peacock, C.D. 2004. Hedgehog signalling in foregut malignancy. Biochem. Pharmacol. 68: 1055-1060.

Watkins, D.N., Berman, D.M., Burkholder, S.G., Wang, B., Beachy, P.A., and Baylin, S.B. 2003. Hedgehog signalling within airway epithelial progenitors and in small-cell lung cancer. Nature 422: 313-317.

Weedon, M.N., Lango, H., Lindgren, C.M., Wallace, C., Evans, D.M., Mangino, M., Freathy, R.M., Perry, J.R., Stevens, S., Hall, A.S., et al. 2008. Genome-wide association analysis identifies 20 loci that influence adult height. Nat. Genet. 40: $575-583$

White, A.C., Lavine, K.J., and Ornitz, D.M. 2007. FGF9 and SHH regulate mesenchymal Vegfa expression and development of the pulmonary capillary network. Development 134: 37433752.

Wijgerde, M., McMahon, J.A., Rule, M., and McMahon, A.P. 2002. A direct requirement for Hedgehog signaling for normal specification of all ventral progenitor domains in the presumptive mammalian spinal cord. Genes \& Dev. 16: 2849-2864.

Wijgerde, M., Ooms, M., Hoogerbrugge, J.W., and Grootegoed, J.A. 2005. Hedgehog signaling in mouse ovary: Indian hedgehog and desert hedgehog from granulosa cells induce target gene expression in developing theca cells. Endocrinology 146: 3558-3566.

Xu, J., Srinivas, B.P., Tay, S.Y., Mak, A., Yu, X., Lee, S.G., Yang H., Govindarajan, K.R., Leong, B., Bourque, G., et al. 2006. Genomewide expression profiling in the zebrafish embryo identifies target genes regulated by Hedgehog signaling during vertebrate development. Genetics 174: 735-752.
Yao, H.H., Whoriskey, W., and Capel, B. 2002. Desert Hedgehog/Patched 1 signaling specifies fetal Leydig cell fate in testis organogenesis. Genes \& Dev. 16: 1433-1440.

Yao, S., Lum, L., and Beachy, P. 2006. The ihog cell-surface proteins bind Hedgehog and mediate pathway activation. Cell 125: 343-357.

Zeng, X., Goetz, J.A., Suber, L.M., Scott Jr., W.J., Schreiner, C.M., and Robbins, D.J. 2001. A freely diffusible form of Sonic hedgehog mediates long-range signalling. Nature 411: 716-720.

Zhang, Y. and Kalderon, D. 2001. Hedgehog acts as a somatic stem cell factor in the Drosophila ovary. Nature 410: 599604.

Zhang, X.M., Ramalho-Santos, M., and McMahon, A.P. 2001 Smoothened mutants reveal redundant roles for Shh and Ihh signaling including regulation of $\mathrm{L} / \mathrm{R}$ asymmetry by the mouse node. Cell 105: 781-792.

Zhang, C., Williams, E.H., Guo, Y., Lum, L., and Beachy, P.A. 2004. Extensive phosphorylation of Smoothened in Hedgehog pathway activation. Proc. Natl. Acad. Sci. 101: 1790017907.

Zhang, L., Chen, X.M., Sun, Z.J., Bian, Z., Fan, M.W., and Chen, Z. 2006. Epithelial expression of SHH signaling pathway in odontogenic tumors. Oral Oncol. 42: 398-408.

Zhang, Q., Zhang, L., Wang, B., Ou, C.Y., Chien, C.T., and Jiang, J. 2006. A hedgehog-induced BTB protein modulates hedgehog signaling by degrading Ci/Gli transcription factor. Dev. Cell 10: 719-729.

Zhao, Y., Tong, C., and Jiang, J. 2007. Hedgehog regulates smoothened activity by inducing a conformational switch. Nature 450: 252-258.

Zhu, A.J. and Scott, M.P. 2004. Incredible journey: How do developmental signals travel through tissue? Genes \& Dev. 18: 2985-2997. 


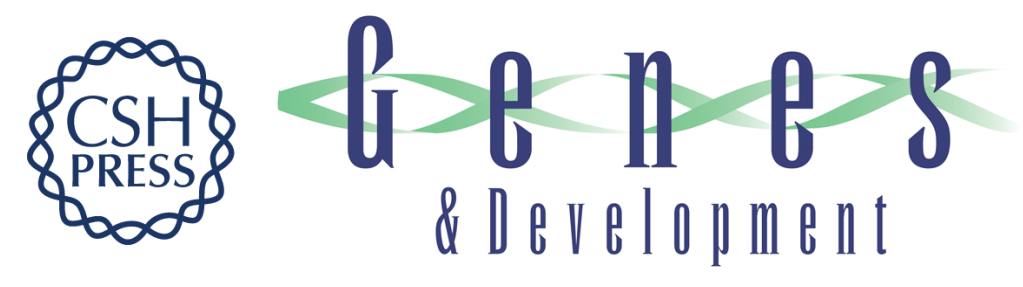

\section{Hedgehog: functions and mechanisms}

Markku Varjosalo and Jussi Taipale

Genes Dev. 2008, 22:

Access the most recent version at doi:10.1101/gad.1693608

References This article cites 264 articles, 112 of which can be accessed free at: http://genesdev.cshlp.org/content/22/18/2454.full.html\#ref-list-1

License Freely available online through the Genes \& Development Open Access option.

Email Alerting Receive free email alerts when new articles cite this article - sign up in the box at the top Service right corner of the article or click here.

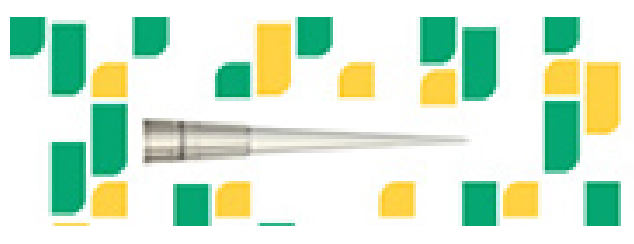

Focused on your science. 